\title{
KONVERSI LAHAN HUTAN MANGROVE SERTA UPAYA PENDUDUK LOKAL DALAM MEREHABILITASI EKOSISTEM MANGROVE
}

\author{
Mangrove Forest Conservation and The Role of Local Community in Mangrove Ecosytems \\ Rehabilitations
}

Konny Rusdianti ${ }^{*}$ dan Satyawan Sunito

Departemen Sains Komunikasi dan Pengembangan Masyarakat, Fakultas Ekologi Manusia, IPB

*)Email : rusdiantik@yahoo.co.id

Diterima 20 Februari 2012 / Disetujui 2 April 2012

\begin{abstract}
Mangrove ecosystem has many benefits both ecological and economic terms because of the mangrove ecosystem is one that has an important role in efforts to make use of sustainable coastal and marine resources. Various alternatives can be made to the management of mangrove forests in accordance with the necessities of life, their ability and their views or perceptions of mangrove forests. But there are still errors in the use of mangrove ecosystems, such as exploiting the mangrove forest and convert it into ponds, residential, agricultural land, and so forth. Various activities are causing widespread decline in mangrove forests and also resulted in decreased function and mangrove benefits for residents and the surrounding environment. To restore function of damaged mangrove and benefits, it is necessary to the management efforts through the rehabilitation and conservation of mangroves. This study aims: (1) Reviewing the chronology of mangrove conversion into ponds that occur in the Village Karangsong, Indramayu District, Indramayu District, (2) Knowing the actors and their respective roles in the conversion process and the actors in the rehabilitation and conservation of mangroves, (3) Analyze perceptions of local residents towards the rehabilitation and conservation of mangroves and to know the perspective of rehabilitation and conservation activities in the conversion of existing conditions, (4) Knowing the shape and development of resident participation in mangrove rehabilitation efforts. The results showed that the conversion of mangrove was originally introduced by settlers from the Losari District, Cirebon. Over time, indirectly Karangsong Village residents to observe and study the fish farming in ponds, and also facilitates the Village Government Karangsong arise in the mangrove area of land to be used by residents as fishponds. The continued development of aquaculture fish and shrimp in the pond, the conversion of mangrove area also do so causes a decrease in mangrove forest area and also resulted in decreased function and mangrove benefits for residents and the surrounding environment. Growing mangrove destruction, making some local residents are aware and take the initiative to form a group that deal with rehabilitation of mangrove on the basis of consciousness that is one of the mangrove ecosystem plays an important role in the ongoing effort to make use of coastal resources, the sea and the surrounding residents. Most of the perceptions of respondents in the category of "Medium" is the perception by the number of scores obtained from scoring high in doubt of the existence of mangrove rehabilitation in conversion of the existing conditions in the Karangsong Village. It can affect their initiative to participate in rehabilitation activities. Village regulations regarding the management of mangrove protection areas are not so clearly known to the respondent. Of the 34 respondents interviewed, nearly all do not know what the Village Regulations.
\end{abstract}

Keywords: mangrove ecosystems, conversion and rehabilitations

\section{PENDAHULUAN}

\section{Latar Belakang}

Indonesia merupakan suatu negara kepulauan yang terdiri dari 13.667 pulau dan mempunyai wilayah pantai sepanjang 54.716 kilometer. Wilayah pantai (pesisir) ini banyak ditumbuhi hutan mangrove. Luas hutan mangrove di Indonesia sekitar 4.251.011,03 hektar dengan penyebaran: 15,46 persen di Sumatera, 2,35 persen di Sulawesi, 2,35 persen di Maluku, 9,02 persen di Kalimantan, 1,03 persen di Jawa, 0,18 Bali dan Nusa Tenggara, dan 69,43 persen di Irian Jaya (FAO/UNDP, 1990 dalam Hainim, 1996).
Berbagai alternatif pengelolaan dapat dilakukan terhadap hutan mangrove yang ada. Masyarakat lokal misalnya, mereka mengkonversi dan memanfaatkan lahan mangrove sesuai dengan kebutuhan hidup, kemampuan mereka dan pandangan mereka atau persepsi tentang hutan mangrove. Dengan berbagai bentuk pemanfaatan yang ada, menyebabkan terjadinya perbedaan dalam perolehan pendapatan dari usaha mengelola hutan mangrove tersebut.

Pola pemanfaatan yang dilakukan dalam usaha mencukupi kebutuhan hidup sesuai kemampuan yang masyarakat miliki belum tentu benar dengan apa yang seharusnya dilakukan. Hal tersebut dikarenakan masih 
terdapat aktor-aktor yang melakukan kesalahan-kesalahan dalam memanfaatkan ekosistem mangrove, seperti mengeksploitasi lahan hutan mangrove dan mengkonversinya menjadi tambak, pemukiman, lahan pertanian, lahan perkebunan, industri dan/atau lainnya dalam skala besar tanpa memikirkan keberlanjutan ekosistem pesisir itu serdiri.

Berbagai aktivitas manusia tersebut menyebabkan penurunan luas hutan mangrove dan berakibat juga pada penurunan fungsi dan manfaat mangrove bagi penduduk dan lingkungan sekitarnya. Untuk mengembalikan fungsi dan manfaat mangrove yang rusak tersebut, maka diperlukan adanya upaya pengelolaan melalui rehabilitasi dan konservasi mangrove.

Kegiatan rehabilitasi dan konservasi mangrove membutuhkan pengawasan dan pemeliharaan secara berkelanjutan. Kemungkinan keberhasilan rehabilitasi sangat kecil tanpa adanya pengawasan. Keberhasilan rehabilitasi dan konservasi mangrove juga ditentukan oleh beberapa faktor, diantaranya adalah peran serta atau pertisipasi penduduk kawasan itu sendiri (penduduk lokal), karena penduduk lokal merupakan penduduk yang mempunyai kepentingan langsung, baik sebagai sumberdaya maupun sebagai ekosistem dengan fungsifungsi ekologisnya dengan wilayah rehabilitasi dan konservasi.

\section{Rumusan Masalah}

Berdasarkan latar belakang dan penjelasan di atas, maka dirumuskan beberapa masalah yang menjadi pertanyaan dalam penelitian ini, yaitu:

1. Bagaimana kronologi konversi mangrove menjadi tambak yang terjadi di Desa Karangsong, Kecamatan Indramayu, Kabupaten Indramayu?

2. Siapa saja aktor dan apa peran masing-masing dalam proses konversi maupun aktor dalam proses rehabilitasi dan konservasi mangrove di Desa Karangsong, Kecamatan Indramayu, Kabupaten Indramayu?

3. Bagaimana persepsi penduduk lokal terhadap kegiatan rehabilitasi dan konservasi mangrove serta mengetahui perspektif kegiatan rehabilitasi dan konservasi dalam kondisi konversi yang ada sekarang?

4. Apa saja bentuk partisipasi penduduk lokal di dalam usaha rehabilitasi mangrove?

\section{Tujuan Penelitian}

Berdasarkan rumusan masalah yang telah disebutkan di atas, maka tujuan penelitian ini adalah:

1. Mengkaji kronologi konversi mangrove menjadi tambak yang terjadi di Desa Karangsong, Kecamatan Indramayu, Kabupaten Indramayu.

2. Mengetahui aktor dan peran masing-masing dalam proses konversi maupun aktor dalam proses rehabilitasi dan konservasi mangrove di Desa Karangsong, Kecamatan Indramayu, Kabupaten Indramayu.
3. Menganalisis persepsi penduduk lokal terhadap program rehabilitasi dan konservasi mangrove serta mengetahui perspektif kegiatan rehabilitasi dan konservasi dalam kondisi konversi yang ada sekarang di Desa Karangsong, Kecamatan Indramayu, Kabupaten Indramayu.

4. Mengetahui bentuk dan perkembangan partisipasi penduduk dalam usaha rehabilitasi mangrove.

\section{Kegunaan Penelitian}

Mengacu pada tujuan penelitian, maka kegunaan dilaksanakannya penelitian ini terbagi menjadi kegunaan bagi beberapa pihak yang terkait, diantaranya:

1. Masyarakat

Melalui penelitian ini masyarakat dapat menambah wawasan mengenai apa saja manfaat dan fungsi dari ekosistem mangrove beserta pengelolaannya secara berkelanjutan, terutama bagi masyarakat pesisir, Kecamatan Indramayu, Kabupaten Indramayu. Selain itu, penelitian ini diharapkan dapat memperlihatkan bagaimana peran penduduk lokal Desa Karangsong, Indramayu serta pengaruhnya terhadap lingkungan terkait peran dan kepentingan penduduk lokal tersebut sebagai aktor.

\section{Pemerintah}

Penelitian ini dapat digunakan sebagai evaluasi pemerintah dalam melakukan strategi pengelolaan ekosistem mangrove. Jika dalam penelitian ini dapat menjawab bagaimana peran dan kepentingan aktor yang terlibat dalam pengelolaan ekosistem mangrove, maka pemerintah perlu memperhatikan kebijakan yang tepat dan penguatan hukum mengenai pemanfaatan dan pengelolaan ekosistem mangrove tersebut.

\section{Akademis}

Penelitian ini dapat berguna sebagai tambahan literatur bagi penelitian lain yang berkaitan dengan analisis konversi dan rehabilitasi ekosistem mangrove.

\section{PENDEKATAN TEORITIS}

\section{Tinjauan Pustaka}

\section{Ekosistem Hutan Mangrove}

Kata mangrove mempunyai dua arti, pertama sebagai komunitas yaitu komunitas atau penduduk tumbuhan atau hutan yang tahan terhadap kadar garam atau salinitas (pasang surut air laut), dan kedua sebagai individu spesies (Magne, 1968; Supriharyono, 2000 dalam Yuniarti, 2004). Magne kemudian menggunakan istilah mangal apabila berkaitan dengan komunitas hutan dan mangrove untuk individu tumbuhan. Mangrove sering diterjemahkan sebagai komunitas hutan bakau, sedangkan tumbuhan bakau merupakan salah satu jenis dari tumbuhan yang hidup di hutan pasang surut tersebut. Jenis-jenis pohon mangrovenya seperti Avicennia sp, Sonneratia sp, Rhizophora sp, Bruguiera sp, dan Ceriops sp. Jenis ini hampir sama dengan jenis-jenis mangrove yang ada di Philiphina yaitu Rhizophora, Avicennia, Bruguiera, dan Sonneratia (King et al, 2000 dalam Yuniarti, 2004). 
Mangrove (bakau) merupakan komunitas vegetasi pantai tropika yang didominasi oleh beberapa spesies pohon bakau yang mampu tumbuh dan berkembang pada kawasan pasang surut pantai berlumpur. Komunitas ini pada umumnya tumbuh pada kawasan intertidal dan supertidal yang mendapat aliran air yang mencukupi, dan terlindung dari gelombang besar dan arus pasang surut yang kuat. Karena itu hutan mangrove banyak dijumpai di pantai-pantai teluk yang dangkal, estuaria, delta dan kawasan-kawasan pantai yang terlindung (Dahuri et al, 2001 dalam Yuniarti, 2004).

Pohon-pohon mangrove adalah halofit, artinya bahwa mangrove ini tahan akan tanah yang mengandung garam dan genangan air laut. Ada juga mangrove tumbuh di tempat yang lebih tinggi, sehingga akan mengalami masa tanpa di genangan air laut yang agak panjang. Namun beberapa pohon mangrove dapat dijumpai di tepi sungai sekitar $100 \mathrm{~km}$ dari laut, walaupun dipermukaan air dimana pohon itu tumbuh adalah air tawar, tetapi pada dasar sungai terdapat seiris air asin (Anwar et al, 1984 dalam Irwan, 2003).

Hutan mangrove merupakan sumberdaya alam daerah tropis yang mempunyai manfaat ganda baik dari aspek sosial ekonomi maupun ekologi. Besarnya ekosistem mangrove bagi kehidupan dapat diketahui dari banyaknya jenis hewan baik yang hidup di perairan, di atas lahan maupun di tajuk-tajuk pohon mangrove atau manusia yang bergantung pada hutan mangrove tersebut (Naamin, 1991 dalam Azis, 2006).

\section{Manfaat dan Fungsi Hutan Mangrove}

Ekosistem hutan mangrove mempunyai manfaat penting dalam mendukung kehidupan manusia baik langsung maupun tidak langsung. Dahuri et al. (1996) dalam Azis (2006) menyatakan bahwa secara garis besar ekosistem hutan mangrove mempunyai dua fungsi utama, yaitu fungsi ekologis dan fungsi sosial ekonomi.

\section{Fungsi Ekologis Hutan Mangrove}

Mangrove merupakan salah satu ekosistem yang mempunyai peranan penting dalam upaya pemanfataan berkelanjutan sumberdaya pesisir dan laut, yang memiliki fungsi penting sebagai penyambung ekologi darat dan laut, serta gejala alam yang ditimbulkan oleh perairan, seperti abrasi, gelombang dan badai. Disamping itu juga merupakan penyangga kehidupan sumberdaya ikan, karena ekosistem mangrove merupakan daerah pemijahan (spawning ground), daerah asuhan (nursery ground) dan daerah mencari makan (feeding ground) (Departemen Kelautan dan Perikanan, 2009).

Ujung Kulon Conservation Society (2010) menyebutkan beberapa fungsi hutan mangrove secara ekologis, diantaranya fungsi fisik dan fungsi biologis. Fungsi fisik, menjaga garis pantai agar tetap stabil, melindungi pantai dari erosi (abrasi) dan intrusi air laut, peredam gelombang dan badai, penahan lumpur, penangkap sedimen, pengendali banjir, mengolah bahan limbah, penghasil detritus, memelihara kualitas air, penyerap $\mathrm{CO} 2$ dan penghasil $\mathrm{O} 2$ serta mengurangi resiko terhadap bahaya tsunami.
Fungsi ekologis mangrove menurut Dahuri et al. 1996) dalam Azis (2006) adalah sebagi berikut:

a. Dalam ekosistem hutan mangrove terjadi mekanisme hubungan antara ekosistem mangrove dengan jenisjenis ekosistem lainnya seperti padang lamun dan terumbu karang.

b. Dengan sistem perakaran yang kokoh ekosistem hutan mangrove memiliki kemampuan meredam gelombang, menahan lumpur dan melindungi pantai dari abrasi, gelombang pasang dan topan.

c. Sebagai pengendali banjir, hutan mangrove yang banyak tumbuh di daerah estuaria juga dapat berfungsi untuk mengurangi bencana banjir.

d. Hutan mangrove dapat berfungsi sebagai penyerap bahan pencemar (environmental service), khususnya bahan-bahan organik.

e. Sebagai penghasil bahan organik yang merupakan mata rantai utama dalam jaring-jaring makanan di ekosistem pesisir, serasah mangrove yang jatuh dan gugur ke dalam air akan menjadi substrat yang baik bagi bakteri dan sekaligus berfungsi membantu proses daun-daun tersebut menjadi detritus. Selanjutnya detritus menjadi bahan makanan bagi hewan pemakan, seperti cacing, udang-udang kecil dan akhirnya hewan-hewan ini akan menjadi makanan larva ikan, udang, kepiting dan hewan lainnya.

f. Merupakan daerah asuhan (nursery ground) hewanhewan muda (juvenile stage) yang akan bertumbuh kembang menjadi hewan-hewan dewasa dan juga merupakan daerah pemijahan (spawning ground) beberapa perairan seperti udang, ikan dan kerangkerangan.

\section{Fungsi Sosial dan Ekonomi Hutan Mangrove}

Manfaat sosial ekositem mangrove adalah dapat digunakan sebagai pemukiman penduduk dan peruntukan kemaslahatan manusia lainnya. Ujung Kulon Conservation Society (2010) menyebutkan beberapa fungsi sosial ekonomi hutan mangrove, diantaranya:

Sumber mata pencarian, produksi berbagai hasil hutan (kayu, arang, obat dan makanan), sumber bahan bangunan dan kerajinan, tempat wisata alam, objek pendidikan dan penelitian, areal pertambakan, tempat pembuatan garam dan areal perkebunan. Kulit batang pohonnya dipakai untuk bahan pengawet dan obat-obatan. Macam-macam obat dapat dihasilkan dari tanaman mangrove. Campuran kulit batang beberapa spesies mangrove tertentu dapat dijadikan obat penyakit gatal atau peradangan pada kulit. Secara tradisional tanaman mangrove dipakai sebagai obat penawar gigitan ular, rematik, gangguan alat pencernaan dan lain - lain. Getah sejenis pohon yang berasosiasi dengan mangrove (blind-your-eye mangrove) atau Excoecaria agallocha dapat menyebabkan kebutaan sementara bila kena mata, akan tetapi cairan getah ini mengandung cairan kimia yang dapat berguna untuk mengobati sakit akibat sengatan hewan laut.

Air buah dan kulit akar mangrove muda dapat dipakai mengusir nyamuk. Air buah tancang dapat dipakai sebagai pembersih mata. Kulit pohon tancang digunakan 
secara tradisional sebagai obat sakit perut dan menurunkan panas. Di Kambodia bahan ini dipakai sebagai penawar racun ikan, buah tancang dapat membersihkan mata, obat sakit kulit dan di India dipakai menghentikan pendarahan. Daun mangrove bila di masukkan dalam air bisa dipakai dalam penangkapan ikan sebagai bahan pembius yang memabukkan ikan (stupefied).

Mangrove bukan sekedar pencegah abrasi. Ia bisa disulap menjadi beragam-ragam makanan. Salah satunya getuk goreng. Mangrove juga dapat dibuat menjadi jenis produk yang lainnya seperti dodol dan tape. Apalagi sebelumnya, para petambak Blanakan telah berhasil mengembangkan produk minuman dari buah salah satu jenis mangrove, yakni Sonerratia caseolaris. Orang-orang menamainya jus pidada. Diimbuhi gula dengan takaran yang pas, rasa minuman itu asam-manis yang menyegarkan.

Ekosistem mangrove merupakan penghasil detritus, sumber nutrien dan bahan organik yang dibawa ke ekosistem padang lamun oleh arus laut. Ekosistem lamun berfungsi sebagai penghasil bahan organik dan nutrien yang akan dibawa ke ekosistem terumbu karang. Selain itu, ekosistem lamun juga berfungsi sebagai penjebak sedimen (sedimen trap) sehingga sedimen tersebut tidak mengganggu kehidupan terumbu karang. Selanjutnya ekosistem terumbu karang dapat berfungsi sebagai pelindung pantai dari hempasan ombak (gelombang) dan arus laut.

Anwar dan Gunawan (2007) menjelaskan bahwa keberadaan hutan mangrove juga penting bagi pertanian di sepanjang pantai terutama sebagai pelindung dari hempasan angin, air pasang, dan badai. Budidaya lebah madu juga dapat dikembangkan di hutan mangrove. Bunga dari Sonneratia sp. dapat menghasilkan madu dengan kualitas baik. Areal hutan mangrove yang masih terkena pasang surut dapat dijadikan pembuatan garam yang dapat dilakukan dengan perebusan air laut dengan kayu bakar dari kayu-kayu mangrove yang mati.

Selain untuk pertanian, hutan mangrove juga dapat dijadikan sebagai kawasan wisata alam. Kegiatan wisata ini disamping memberikan pendapatan langsung bagi pengelola melalui penjualan tiket masuk dan parkir, juga mampu menumbuhkan perekonomian penduduk di sekitarnya dengan menyediakan lapangan kerja dan kesempatan berusaha, seperti membuka warung makan, menyewakan perahu, dan menjadi pemandu wisata.

\section{Konversi Lahan Mangrove}

\section{Faktor Penyebab Konversi Lahan Mangrove}

Tambak dalam skala kecil tidak terlalu banyak mempengaruhi ekosistem mangrove, tapi lain halnya bila dalam skala besar. Konversi mangrove yang luas menjadi tambak dapat mengakibatkan penurunan produksi perikanan di perairan sekitarnya. Pertambakan ini juga diduga dapat memengaruhi produktivitas perairan estuari dan laut di sekitarnya. Seperti contoh menurunnya produksi udang laut sebagai akibat menciutnya luas hutan mangrove (Saparinto, 2007 dalam Setiawan, 2010) .

Kondisi sosial ekonomi penduduk yang bermukim di daerah pesisir secara umum akan mempengaruhi ekosistem mangrove. Konversi hutan mangrove menjadi areal tambak merupakan salah satu penyebab kerusakan hutan mangrove. Berdasarkan kriteria penilaian sosial ekonomi sebagai penyebab kerusakan hutan mangrove, faktor-faktor yang dilihat adalah (1) mata pencaharian utama (mp), (2) lokasi lahan usaha (llu), (3) pemanfaatan kayu bakar (pkb), dan (4) persepsi terhadap mangrove (Departemen Kehutanan, 2006).

\section{Dampak Konversi Terhadap Fungsi Ekologis dan Sosial Ekonomis Hutan Mangrove}

Terdapat dua jenis dampak konversi dan pemanfaatan hutan mangrove, yaitu: (1) dampak terhadap lingkungan fisik dan biologis; dan (2) dampak terhadap lingkungan sosial ekonomi. Dampak fisik dan biologis yang dimaksud di sini adalah berkaitan dengan aspek amunitas dan ketersediaan sumber penghasilan dari keberadaan hutan mangrove di kawasan sekitar tempat tinggal penduduk. Dampak ini pula berupa penurunan keragaman, stabilitas, dan produktifitas biologis (Jakaria, 2000)

Dampak sosial ekonomi, konversi/penebangan hutan haruslah dikaitkan dengan keuntungan dan kerugian dan bentuk nilai uang, perubahan keindahan alam, tingkah laku, keamanan dan kesehatan penduduk (Soerianegara, 1982 dalam Jakaria, 2000). Disamping itu pula sangat berpengaruh kepada lapangan kerja dan pendapatan daerah. Jadi aspek yang perlu diperhatikan dalam kaitannya dengan dampak sosial ekonomi adalah faktor kesempatan kerja, pola kepemilikan dan penguasaan sumberdaya alam, tingkat pendapatan penduduk, tingkat sarana dan prasarana perekonomian dan pola pemanfaatan sumberdaya alam (Hadi, 1995 dalam Jakaria, 2000).

Pada ekosistem mangrove, rantai makanan yang terjadi adalah rantai makanan detritus. Sumber utama detritus adalah hasil penguraian guguran daun mangrove yang jatuh ke perairan oleh bakteri dan fungi (Romimohtarto dan Juwana, 1999 dalam Setiawan, 2010).

Rantai makanan detritus dimulai dari proses penghancuran luruhan dan ranting mangrove oleh bakteri dan fungi (detritivor) menghasilkan detritus. Hancuran bahan organik (detritus) ini kemudian menjadi bahan makanan penting (nutrien) bagi cacing, crustacea, moluska, dan hewan lainnya (Nontji, 1993 dalam Setiawan, 2010). Setyawan dkk (2002) dalam Setiawan (2010) menyatakan nutrien di dalam ekosistem mangrove dapat juga berasal dari luar ekosistem, dari sungai atau laut. Lalu ditambahkan oleh Romimohtarto dan Juwana (1999) dalam Setiawan (2010) yang menyatakan bahwa bakteri dan fungi tadi dimakan oleh sebagian protozoa dan avertebrata. Kemudian protozoa dan avertebrata dimakan oleh karnivor sedang, yang selanjutnya dimakan oleh karnivor tingkat tinggi. Karena dengan adanya lahan hutan mangrove yang dikonversi ini fauna-fauna baik itu pemangsa maupun yang dimangsa akan berpindah ke lahan yang belum mengalami kerusakan. Contohnya saja spesies monyet dan bangau mungkin tidak akan ada lagi karena spesies ikan yang ada akan berkurang dan habitat mereka telah rusak. Pengaruh bahan-bahan kimia dari pupuk pertanian juga. Secara tidak langsung akan 
mengubah siklus biogeokimianya karena unsur-unsur yang ada akan berubah dan berkurang.

\section{Pengelolaan Ekosistem Mangrove}

Pengelolaan sumberdaya alam adalah upaya manusia dalam mengubah sumberdaya alam agar diperoleh manfaat yang maksimal dengan mengutamakan kontinuitas produksi (Soerianegara, 1977 dalam Harahap 2001). Davis (1960) dalam Harahap (2001) menyatakan bahwa tujuan utama pengelolaan hutan, termasuk hutan mangrove adalah untuk mempertahankan produktivitas lahan hutan sehingga kelestarian hasil merupakan tujuan utama pengelolaan hutan. Kelestarian produktivitas mempunyai dua arti, yaitu kesinambungan pertumbuhan dan kesinambungan hasil panen.

Menurut Bengen (2001) dalam Haikal (2008), menyebutkan bahwa pelestarian hutan mangrove merupakan suatu unit usaha yang kompleks untuk dilaksanakan karena kegiatan tersebut sangat membutuhkan sifat akomodatif terhadap pihak-pihak terkait baik yang berbeda di sekitar maupun di luar kawasan. Kegiatan pelestarian mangrove pada dasarnya dilakukan demi memenuhi kebutuhan dari berbagai kepentingan. Sifat akomodatif tersebut akan lebih dirasakan manfaatnya bila keberpihakan pada institusi yang rentan terhadap sumberdaya mangrove, diberikan porsi yang lebih besar. Untuk itu yang perlu diperhatikan adalah menjadikan penduduk sebagai komponen penggerak pelestarian hutan mangrove.

\section{Rehabilitasi Hutan Mangrove}

Rehabilitasi merupakan kegiatan/upaya, termasuk didalamnya pemulihan dan penciptaan habitat dengan mengubah sistem yang rusak menjadi yang lebih stabil. Pemulihan merupakan suatu kegiatan untuk menciptakan suatu ekositem atau memperbaharuinya untuk kembali pada fungsi alamiahnya. Namun demikian, rehabilitasi mangrove sering diartikan secara sederhana, yaitu menanam mangrove atau membenihkan mangrove lalu menanamnya tanpa adanya penilaian yang memadai dan evaluasi terhadap keberhasilan penanaman dan level ekosistem. Selain itu untuk alasan ekonomi usaha pemulihan kembali ekosistem mangrove sering kali terbatas pada jenis-jenis tertentu dari mangrove (2 atau 3 jenis spesies). Hal ini menyebabkan perubahan terhadap habitat dan penurunan fungsi ekologi ekosistem mangrove tersebut karena sifatnya yang homogen dibendingkan dengan yang alami (heterogen dan banyak spesies), yang merupakan biodiversitas dalam kaitannya dengan kekayaan genetik (Macintosh et al., 2002 dalam Haikal, 2008).

\section{Konsep Persepsi}

Persepsi adalah pandangan, penilaian, interpretasi, harapan, atau aspirasi seseorang terhadap obyek. Persepsi dibentuk melalui serangkaian proses (kognisi) yang diawali dengan menerima rangsangan atau stimulus dari obyek oleh indera (mata, hidung, telinga, kulit dan mulut) dan dipahami dengan interpretasi atau penafsiran tentang obyek yang dimaksud. Bakat minat, kemauan, perasaan, fantasi, kebutuhan, motivasi, jenis kelamin, umur, kepribadian, kebiasaan dan lain-lain serta sifat lain yang khas yang dimiliki oleh seseorang. Persepsi dipengaruhi oleh faktor budaya dan sosial ekonomi seperti pendidikan, lingkungan tempat tinggal dan suku bangsa (Harihanto, 2001).

Rakhmat (2007) menjelaskan bahwa persepsi dapat berupa kesan, penafsiran atau penilaian berdasarkan pengalaman yang diperoleh dan suatu proses pengambilan keputusan tentang pemahaman seseorang kaitannya dengan suatu obyek, stimuli atau individu yang lain. Kesan stimuli tersebut dapat dipandang sebagai pengalaman tentang obyek, peristiwa atau hubungan yang diperoleh dengan menyimpulkan informasi dan menafsirkan pesan.

Menurut Calhoun dan Acocella (1990), persepsi memiliki tiga dimensi yang menandai konsep dirinya, yaitu:

1. Pengetahuan merupakan apa yang kita ketahui (atau kita anggap tahu) tentang pribadi lain-wujud lahiriah, perilaku, masa lalu, perasaan motif dan sebagainya.

2. Penghargaan merupakan gagasan kita tentang orang itu menjadi apa dan mau melakukan apa yang dipadukan dengan gagasan kita tentang seharusnya dia menjadi apa dan melakukan apa.

3. Evaluasi merupakan kesimpulan kita tenteng seseorang didasarkan pada bagaimana seseorang (menurut pengetahuan kita tentang mereka) memenuhi pengharapan kita tentang dia.

Susiastik (1998) menjelaskan bahwa tinggi rendahnya tingkat persepsi seseorang atau kelompok akan mendasari atau mempengaruhi tingkat peran serta dalam kegiatan. Tingkat persepsi yang tinggi merupakan dasar dukungan dan motivasi positif untuk berperan serta, begitu pula sebaliknya tingkat persepsi yang rendah atau kurang dapat merupakan penghambat bagi seseorang atau kelompok orang untuk berperan serta dalam pelaksanaan kegiatan.

\section{Kerangka Pemikiran}

Menurut Departemen Kelautan Dan Perikanan (2009), mangrove merupakan salah satu ekosistem yang mempunyai peranan penting dalam upaya pemanfataan berkelanjutan sumberdaya peisir dan laut, yang memiliki fungsi penting sebagai penyambung ekologi darat dan laut, serta gejala alam yang ditimbulkan oleh perairan, seperti abrasi, gelombang dan badai. Disamping itu juga merupakan penyangga kehidupan sumber daya ikan, karena ekosistem mangrove merupakan daerah pemijahan (spawning ground), daerah asuhan (nursery ground) dan daerah mencari makan (feeding ground).

Manfaat sosial ekositem mangrove adalah dapat digunakan sebagai pemukiman penduduk dan peruntukan kemaslahatan manusia lainnya. Ujung Kulon Conservation Society (2010) menyebutkan beberapa fungsi sosial ekonomi hutan mangrove sebagai sumber mata pencarian, diantaranya produksi berbagai hasil hutan (kayu, arang, obat dan makanan), sumber bahan bangunan dan kerajinan, tempat wisata alam, objek pendidikan dan penelitian, areal pertambakan, tempat pembuatan garam dan areal perkebunan.

Kondisi hutan mangrove yang bersifat open access tersebut membuat masyarakat dapat memanfaatkan SDA 
secara terbuka, baik secara ekologis maupun ekonomis. Namun perbandingan antara kedua pemanfaatan di atas, manfaat ekonomis lebih cenderung diutamakan oleh
Ekosistem Mangrove ini dapat dirangkum dalam Gambar 1.

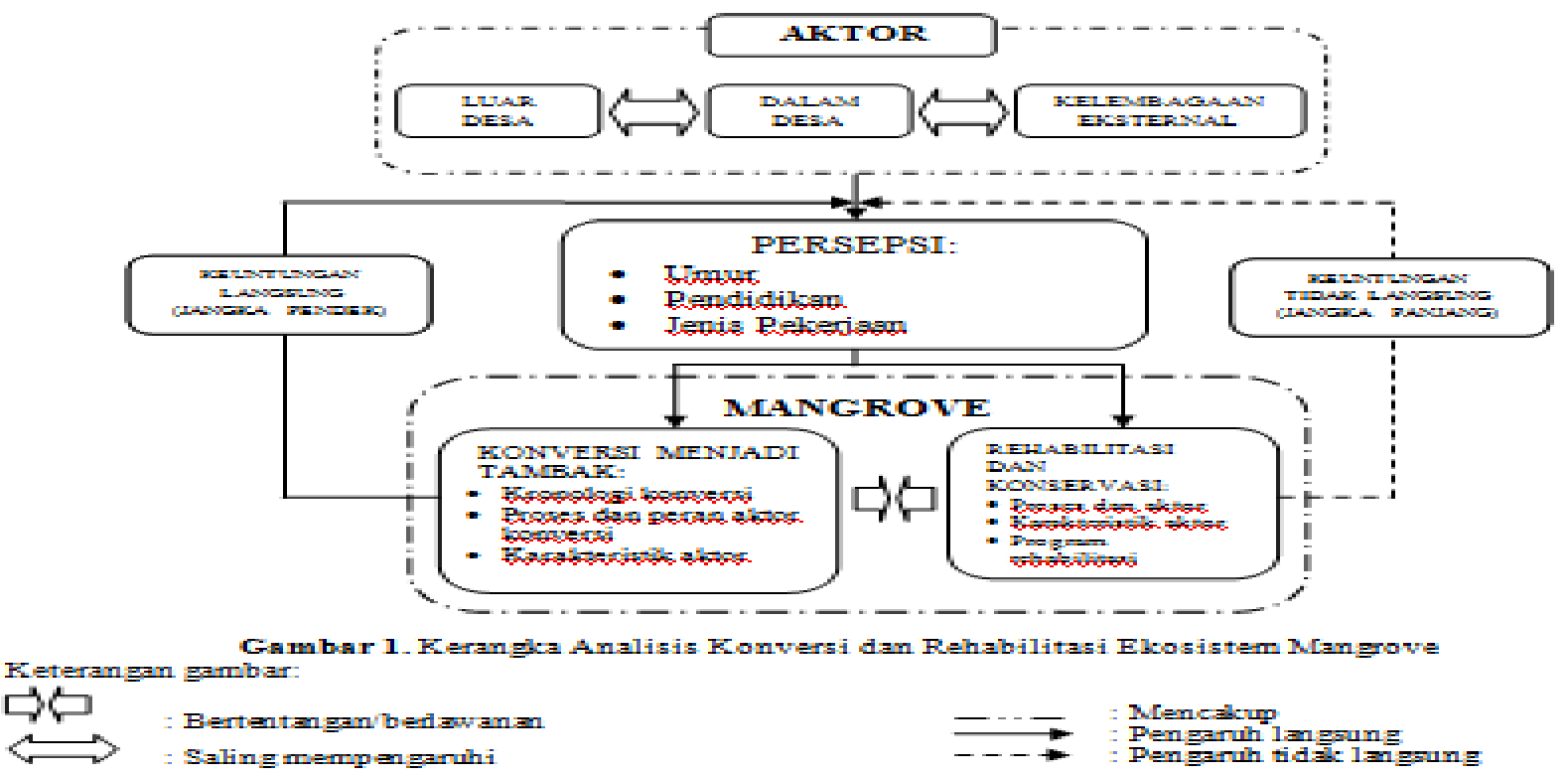

penduduk lokal karena memberikan keuntungan yang dirasakan dalam jangka pendek (seperti pemanfaatan dengan cara mengkonversi lahan mangrove), dibandingkan dengan manfaat ekologis yang memberikan keuntungan dalam jangka panjang. Menurut Setiawan (2010), faktor utama yang menjadi permasalahan dan penyebab terjadinya konversi mangrove antara lain adalah tekanan penduduk untuk kebutuhan ekonomi yang tinggi sehingga permintaan konversi mangrove juga semakin tinggi. Penduduk disini lebih mementingkan kebutuhannya sendiri-sendiri dibandingkan kepentingan ekologis dan kepedulian akan dampak lingkungan hidup. Banyaknya pihak yang tidak bertanggung jawab juga dengan meminta untuk mengkonversi lahan mangrove tapi setelah dikonversi lahan tersebut mereka tidak menindak lanjutinya.

Kerusakan ekosistem tersebut memerlukan adanya upaya rehabilitasi yaitu kegiatan/upaya termasuk didalamnya pemulihan dan penciptaan habitat dengan mengubah sistem yang rusak menjadi lebih stabil (Macintosh et al., 2002 dalam Haikal, 2008).

Upaya rehabilitasi yang dilakukan memerlukan partisipasi aktif dari penduduk lokal, diantaranya adalah aktor atau pelaku konversi. Namun peran serta penduduk lokal itu sendiri juga dipengaruhi oleh persepsi atau pandangan, penilaian, interpretasi, harapan, atau aspirasi seseorang terhadap obyek (Harihanto, 2001). Seperti yang dijelaskan oleh Susiastik (1998) bahwa tinggi rendahnya tingkat persepsi seseorang atau kelompok akan mendasari atau mempengaruhi tingkat peran serta dalam kegiatan. Tingkat persepsi yang tinggi merupakan dasar dukungan dan motivasi positif untuk berperan serta, begitu pula sebaliknya tingkat persepsi yang rendah atau kurang dapat merupakan penghambat bagi seseorang atau kelompok orang untuk berperan serta dalam pelaksanaan kegiatan.

Penelitian mengenai Konversi Lahan Hutan Mangrove Serta Upaya Penduduk Lokal Dalam Rehabilitasi
Berdasarkan Gambar 1, terdapat beberapa aktor yang dapat berperan serta dalam konversi maupun rehabilitasi mangrove di Desa Karangsong, Kecamatan Indramayu, Kabupaten Indramayu, diantaranya adalah penduduk lokal yang secara langsung maupun tidak langsung mendapatkan dampak positif dan negatif dengan adanya konversi dan pengelolaan mangrove di kawasan tersebut serta aktor lain selain penduduk lokal yaitu diantaranya adalah kelembagaan eksternal (LSM, Departemen Kehutanan dan Perkebunan, dan lainnya) serta aktor dari luar desa atau luar penduduk lokal, sedangkan beberapa aktor tersebut tadi memiliki hubungan yang saling mempengaruhi satu sama lain.

Aktor dalam desa maupun aktor luar desa masing-masing memiliki persepsi mengenai ekosistem mangrove. Persepsi tersebut dapat mempenguruhi keputusan aktor dalam menentukan bentuk pemanfaatan dalam mengelola ekosistem mangrove, baik pengelolaan dalam bentuk konversi maupun rehabilitasi atau konservasi mangrove.

Dampak dari konversi dan rehabilitasi mangrove dapat berupa keuntungan/kerugian secara langsung maupun tidak langsung. Seperti dengan memanfaatakan mangrove melalui konversi, keuntungan langsung atau dalam jangka pendek dapat diperoleh oleh aktor terutama penduduk lokal. Oleh karena itu, sebagian besar penduduk lokal lebih mementingkan kepentingan ekonomi mereka yaitu dengan mengkonversi lahan mangrove menjadi tambak dalam skala luas. Berbeda dengan upaya rehabilitasi dan konservasi ekosistem mangrove yang bertujuan untuk melestarikan mangrove memang tidak memberikan keuntungan dalam jangka pendek melainkan keuntungan yang dapat dirasakan oleh penduduk dalam jangka panjang sehingga hanya sebagian kecil penduduk yang memiliki minat untuk terlibat dalam kegiatan tersebut. 


\section{Hipotesis Penelitian}

Berdasarkan kerangka pemikiran di atas, maka hipotesis penelitian adalah sebagai berikut:

1. Diduga pengambilan keputusan dalam menentukan pola pengelolaan mangrove dipengaruhi oleh persepsi masing-masing individu terhadap mangrove.

2. Diduga kegiatan konversi mangrove lebih memberikan keuntungan jangka pendek bagi sebagian besar dari penduduk lokal.

3. Diduga adanya kegiatan rehabilitasi mangrove merugikan sebagian besar aktor konversi/petambak.

4. Diduga program rehabilitasi dan konservasi didukung oleh sebagian penduduk yang bukan pelaku tambak.

\section{Definisi Operasional}

1. Umur adalah selisih antara tahun responden dilahirkan dengan tahun pada saat penelitian dilaksanakan. Umur responden terbagi dalam tiga rentang usia, yaitu

$$
\begin{array}{ll}
\text { - } & \text { Sangat Produktif }(25<\mathrm{x} \leq 45) \\
\text { - } & \text { Produktif }(45<\mathrm{x} \leq 65) \\
& \text { Tidak Produktif }(25>\mathrm{x}>65)
\end{array}
$$

2. Pendidikan Terakhir adalah jenjang pendidikan formal terakhir yang pernah dijalani responden hingga mendapat predikat lulus. Tingkat pendidikan diukur dengan mangajukan pertanyaan langsung kepada responden.

3. Jenis pekerjaan utama adalah profesi yang paling utama yang dijalankan responden untuk mencukupi kebutuhan hidupnya. Jenis pekerjaan utama diukur dengan mengajukan pertanyaan langsung kepada responden.

4. Luas lahan tambak adalah besarnya lahan garapan yang dikuasai responden petani tambak, dan dinyatakan dengan satuan hektar (ha). Dalam penelitian ini luas lahan tambak diklasifikasikan menjadi dua berdasarkan data di lapangan, yaitu:

$$
\begin{aligned}
\text { - } & \alpha \leq 5 \text { ha } \\
\text { - } & \alpha>5 \text { ha }
\end{aligned}
$$

5. Status penguasaan lahan tambak adalah bentuk-bentuk penguasaan warga terhadap lahan secara efektif, meliputi:

$$
\begin{array}{ll}
\text { - } & \text { Pemilik } \\
\text { - } & \text { Penyewa } \\
\text { - Penggarap }
\end{array}
$$

6. Persepsi penduduk adalah kecenderungan individu untuk menanggapi suatu objek, kaitannya dalam penelitian ini yaitu persepsi yang mencakup keberadaan mangrove, konversi mangrove menjadi tambak atau mengenai keberadaan tambak dan adanya program rehabilitasi mangrove di Desa Karangsong, Kecamatan Indramayu, Kabupaten Indramayu.
Setiap responden diberikan 9 pernyataan yang

\begin{tabular}{|c|}
\hline Setuju \\
\hline Netral/ragu-ragu \\
\hline Tidak setuju \\
\hline
\end{tabular}
mencakup keberadaan mangrove, konversi mangrove menjadi tambak atau mengenai keberadaan tambak dan adanya program rehabilitasi mangrove di Desa Karangsong, Kecamatan Indramayu, Kabupaten Indramayu, kemudian masing-masing pernyataan tersebut diberi skor berdasarkan jawaban yang diberikan oleh responden, yaitu:

Penjumlahan dari kode setiap pernyataan dari masingmasing pernyataan disebut sebagai skor (x). Maka total skor minimum seluruh pernyataan $=0$, Sedangkan total skor maksimum pernyataan $=18$. Berikut adalah skor interval persepsi dari total skor maksimum:

- Persepsi kategori "Tinggi”, dengan skor berada pada interval: $13 \leq \mathrm{x} \leq 18$

- Persepsi kategori "Sedang", dengan skor berada pada interval: $7 \leq \mathrm{x} \leq 12$

- Persepsi kategori "Rendah", dengan skor berada pada interval: $0 \leq \mathrm{x} \leq 6$

\section{PENDEKATAN LAPANG}

\section{Lokasi dan Waktu Penelitian}

Penelitian dilaksanakan di Desa Karangsong, Kecamatan Indramayu, Kabupaten Indramayu, Provinsi Jawa Barat. Lokasi penelitian dipilih secara sengaja (purposive) dengan pertimbangan bahwa Desa Karangsong merupakan desa yang memiliki hutan mangrove berkriteria bukan hutan lindung dan terdapat banyak kegiatan konversi menjadi tambak yang dipertahankan, namun di sisi lain kegiatan rehabilitasi dan konservasi yang bertentangan dengan kegiatan konversi juga aktif dilaksanakan pada mangrove tersebut. Peta daerah penelitian terdapat pada Lampiran 2. Waktu penelitian dilaksanakan pada bulan April - Juli tahun 2011.

\section{Teknik Pengumpulan Data}

Pendekatan yang dilakukan dalam penelitian ini adalah pendekatan kualitatif didukung dengan data kuantitatif. Pendekatan kualitatif dilakukan untuk mengetahui sejarah konversi mangrove serta rehabilitasinya, dampak yang dirasakan penduduk akibat konversi dan juga aktor-aktor yang terlibat dalam konversi maupun rehabilitasi mangrove. Data kuantitatif dimanfaatkan untuk mengidentifiksai persepsi penduduk lokal responden petambak dan non petambak. Data yang dibutuhkan dalam penelitian ini meliputi:

1. Data sekunder, meliputi hasil dokumentasi yang dimiliki Desa Karangsong, Kabupaten Indramayu, studi literatur dan hasil penelitian sebelumnya (jurnal, tesis, disertasi, makalah dan informasi dari internet).

2. Data primer, diperoleh dari wawancara menggunakan daftar pertanyaan berupa kuesioner dengan responden dan informan untuk mendapatkan data kualitatif maupun data kuantitatif. 


\section{Penentuan Responden dan Informan}

Terdapat dua subjek yang dapat membantu memberikan data primer dalam penelitian ini, yaitu responden dan informan. Responden adalah individu yang memberikan data atau keterangan mengenai dirinya sendiri mencakup karakteristik dan persepsi, sedangkan informan adalah individu yang dapat memberikan data atau keterangan mengenai dirinya sendiri, orang lain (individu maupun kelompok), dan lingkungannya.

Populasi dalam penelitian ini adalah penduduk Desa Karangsong, Kecamatan Indramayu, Kabupaten Indramayu. Sampel dalam penelitian ini yaitu penduduk kawasan mangrove yang ada di desa tersebut. Jumlah responden yang diambil yaitu sebanyak 34 orang. Jumlah responden yang didapatkan dipengaruhhi oleh keterbatasan waktu, biaya dan kemudahan dalam mendapatkan responden. Pembagian jumlah responden ke dalam dua kategori adalah:

1. Non petambak dipilih sebanyak 11 orang yang dipilih secara purposive atau secara sengaja dan dihitung berdasarkan tiap jenis pekerjaan di luar tambak berdasarkan data sekunder yang ada di Kantor Desa Karangsong.

2. Petambak dipilih sebanyak 23 orang karena petambak merupakan aktor yang berhubungan langsung atau dipengaruhi dan mempengaruhi langsung keberadaan mangrove oleh karena itu jumlah sampel yang diambil lebih banyak dibandingkan jumlah sampel non petambak. Karena sifat populasi yang homogen, maka sampel ditentukan dengan menggunakan teknik simple random sampling, yaitu sebuah sampel yang diambil sedemikian rupa sehingga tiap unit penelitian atau satuan elemter dari popolasi mempunyai kesempatan yang sama untuk dipilih sebagai sampel (Singarimbun dan Effendi 1989). Penentuan informan dilakukan berdasarkan teknik snowball sampling. Informan yang dituju dalam penelitian tidak dibatasi, misalnya informan dari Dinas Kehutanan, Perangkat Desa (termasuk ketua RW dan Ketua RT), kelompok nelayan/kelompok petani tambak, kelompok perlindungan kawasan mangrove, serta penduduk diluar perangkat desa yang memiliki pengaruh kuat terhadap desa tersebut (pemangku adat).

\section{Teknik Pengolahan dan Analisis Data}

Pengolahan dan analisis data kualitatif dilakukan dengan pengkajian terhadap hasil wawancara mendalam dan pengamatan disajikan dalam bentuk catatan harian yang dianalisis sejak pertama kali datang ke lapangan dan berlangsung terus menerus selama pengambilan data penelitian.

Data kualitatif dikumpulkan terlebih dahulu kemudian dianalisis menggunakan analisis deskriptif dengan penyajian data dan penarikan kesimpulan untuk melihat bagaimana sejarah lokal konversi mangrove, tujuan konversi mangrove, keuntungan dan kerugian dari konversi mangrove dan semacamnya. Selanjutnya data kuantitatif yang dilakukan dengan teknik pengisian kuesioner dan telah terkumpul diolah dan disajikan dalam bentuk tabel frekuensi yang diolah menggunakan MS
EXCEL 2007, kemudian data diterjemahkan dalam bentuk uraian, penjelasan, presentase, kesimpulan, dan dipaparkan secara deskriptif. Teknik ini digunakan untuk mengetahui karakteristik dan persepsi penduduk lokal mengenai konversi dan rehabilitasi mangrove di Desa Karangsong.

\section{GAMBARAN LOKASI PENELITIAN}

\section{Profil Desa Karangsong}

Sebelum menjadi Desa Karangsong, lokasi penelitian merupakan bagian dari Desa Brondong, Kecamatan Indramayu, Kabupaten Indramayu. Pada tahun 1985, terjadi pemekaran Desa Brondong yang terbagi menjadi tiga desa, yaitu Desa Brondong, Desa Pabean Udik dan Desa Karangsong.

Desa Karangsong merupakan area pesisir pantai utara Jawa Barat. Secara administrasi, sebelah utara Desa Karangsong berbatasan dengan desa Pabean Udik, sebelah selatan berbatasan dengan Desa Tambak, sebelah barat berbatasan dengan Kelurahan Paoman, dan sebelah barat dibatasi oleh Laut Jawa.

Total Luas Desa Karangsong adalah 243,067 ha. Dari luas total tersebut, dominan pemandangan yang ada di desa ini adalah luasnya hamparan lahan tambak/empang milik sebagian warga Desa Karangsong dengan komposisi luas lahan sebesar 204,067 ha. Selain itu, luas lainnya terdiri dari perumahan seluas 7,862 ha, dan pekarangan seluas 23,872 ha. Sedangkan sisanya digunakan untuk sarana prasarana umum seperti tanah wakaf dan tanah kuburan.

Data monografi Desa Karangsong tahun 2010 mencatat jumlah penduduk Desa Karangsong sebanyak 4.677 jiwa, yang terdiri dari 1.890 laki-laki, 2.787 perempuan dan terbagi kedalam 1.532 kepala keluarga. Sebagian besar penduduk Desa Karangsong menganut agama Islam yaitu sebanyak 4.498 orang, 6 orang beragama Kristen dan 6 orang lainnya beragama Hindu.

Sarana dan prasarana yang dimiliki Desa Karangsong terdiri dari sarana/prasarana pendidikan yaitu 2 unit BKB, 3 unit SD, dan 5 unit Madrasah. Sarana/prasarana kesehatan terdiri dari 7 unit Posyandu, 1 unit Poskesdes, 1 unit Puskesmas, 2 orang Bidan Desa, dan 42 orang Kader Posyandu. Sedangkan sarana/prasarana ekonomi yang ada di Desa Karangsong terdiri dari 3 pasar tradisional, 1 Bank Desa, dan 1 KPL (Koperasi Perikanan Laut) Mina Sumitra.

\section{Sistem Penghidupan Penduduk}

Penduduk Desa Karangsong sebagian besar adalah nelayan laut, diantaranya yaitu nelayan dengan perahu besar yang melaut sampai perbatasan Negara Indonesia hingga memakan waktu berbulan-bulan berada di tengah laut, dan nelayan harian yang melaut menggunakan perahu kecil. Mereka membuat sendiri perahu besar atau perahu kecil yang akan dipakai melaut dengan bantuan jasa dari nelayan lain atau ABK (Anak Buah Kapal). Pemilik perahu besar biasanya disebut sebagai "Bos Perahu" karena memiliki modal yang besar untuk membuat perahu. Perahu-perahu besar yang sedang dibuat dapat dilihat di samping aliran sungai menuju laut yang 
menjadi pembatas antara Desa Karangsong dan Desa Pabean Udik.

Seperti yang telah dijelaskan pada profil Desa Karangsong berdasarkan data monografi Desa Karangsong tahun 2010, sebagian besar luas lahan sebesar 204,067 ha dari total luas 243,067 ha di Desa Karangsong dimanfaatkan sebagai tambak/empang budidaya ikan bandeng dan udang windu. Lahan yang dimanfaatkan merupakan tanah milik, namun tidak jarang sebagian dari mereka juga menyewa lahan yang sudah menjadi tambak. Masyarakat yang tidak memiliki dan tidak mampu untuk menyewa tambak, mereka sering kali memanfaatkan aliran sungai atau saluran irigasi tambak untuk mencari ikan atau udang dengan cara menjaring, memasang bubuh, dan anco. Selain itu, masyarakat yang tidak memiliki tambak juga bisa mencari nafkah dengan menjadi buruh atau penggarap tambak dengan tugas mengurusi tambak, memberi makan bandeng/udang, dan pekerjaan lainnya yang dibutuhkan dalam budidaya bandeng maupun udang pada tambak.

Pada tabel 1 disajikan mata pencaharian secara keseluruhan penduduk Desa Karangsong yang diambil dari data monografi desa tahun 2010.

Tabel 1. Mata Pencaharian Penduduk Desa Karangsong

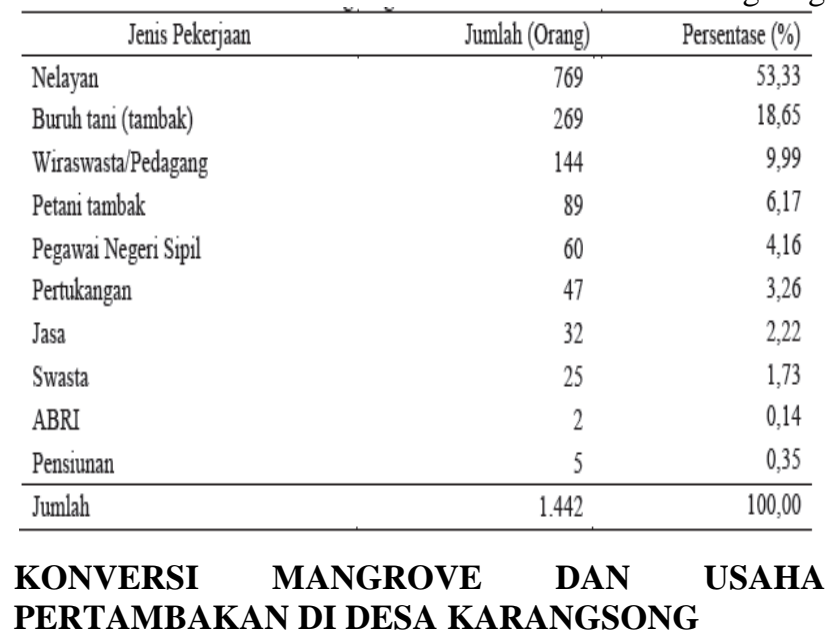

\section{Kronologi Konversi Mangrove}

Sebelum tahun 1960-an, sebagian besar penduduk Desa Karangsong bermatapencaharian sebagai nelayan dan petani atau buruh tani. Sebagian besar dari mereka memanfaatkan laut dan sawah sebagai ladang dalam mencari nafkah dan kebutuhan hidup sehari-hari. Selain itu, warga juga memanfaatkan hutan mangrove yang didominasi oleh jenis api-api (Avicennia sp.) untuk mencari ikan air payau, kepiting, kerang, dan biota lainnya yang dapat menghasilkan keuntungan bagi mereka.

Penduduk Desa Karangsong pada saat itu masih belum memiliki kesadaran mengenai fungsi tanah timbul pada mangrove akibat sedimentasi di sekitar pantai Karangsong yang memberikan keuntungan secara ekonomi, sehingga mereka tidak memanfaatkan dan mengelola lahan tersebut secara maksimal. Pada tahun 1962, terdapat beberapa penduduk pendatang yang berasal dari Kecamatan Losari, Kabupaten Cirebon yang sengaja singgah di Desa Karangsong yang pada saat itu masih merupakan bagian dari Desa Brondong dan mulai membuka tambak sebagai salah satu kegiatan ekonomi mereka. Penduduk Losari memanfaatkan tanah timbul akibat sedimentasi yang ada di Desa Karangsong untuk dijadikan tambak/empang budidaya ikan bandeng dan udang windu. Namun jumlah luas tambak yang dimanfaatkan oleh penduduk Losari pada tanah timbul saat itu masih dalam skala kecil yaitu hanya sekitar 1-2 ha. Tujuan penduduk Losari membuka tambak di Desa Karangsong adalah untuk menambah luas tambak yang mereka miliki sebelumnya di daerah asal mereka. Selain itu, penduduk pendatang tersebut lebih jeli melihat peluang harga tanah yang masih murah di Desa Karangsong pada saat itu dibandingkan tanah di Losari. Murahnya harga tanah di Desa Karangsong dikarenakan penduduk Desa Karangsong yang belum mengerti dengan manfaat tanah timbul tersebut seperti yang telah dijelaskan sebelumnya.

Datangnya penduduk Losari dalam rangka ekspansi tersebut secara tidak langsung telah menjadi perkenalan mengenai tambak dengan memanfaatkan tanah timbul bagi penduduk Desa Karangsong. Seiring berjalannya waktu, banyaknya keuntungan yang diberikan usaha tambak pun semakin membuat kesan baik kepada penduduk Desa Karangsong. Dengan berbagai kesan positif yang diberikan dari usaha tambak tersebut, penduduk lokal mulai tertarik untuk mempelajari bagaimana proses dari awal hingga akhir mengenai budidaya ikan bandeng dan udang windu pada tambak. Hingga pada tahun 1968 penduduk lokal mulai aktif membuka lahan tanah timbul untuk dijadikan tambak dan terjadi pembagian lahan tambak oleh Pemerintah Desa yang saat itu belum terjadi pemekaran desa dan masih termasuk Desa Brondong.

Pada tahun 1982, hutan mangrove yang ada di pesisir Desa Karangsong telah habis karena pembukaan lahan dan konversi menjadi tambak secara berlebihan. Ditambah dengan minimnya pengetahuan sebagian besar penduduk Desa Karangsong saat itu mengenai pentingnya jalur hijau (green belt) dan ekosistem mangrove, penduduk semakin kurang peduli mengenai keberlanjutan ekosistem mangrove. Perkembangan tambak/empang semakin pesat karena tambak dianggap efektif meningkatkan perekonomian keluarga. Pada tahun 1986, harga udang yang tinggi semakin membuat penduduk Desa Karangsong ingin memiliki tambak budidaya udang sehingga permintaan konversi lahan menjadi tambak semakin tinggi. Kondisi lahan pesawahan di Desa Karangsong merupakan sawah dengan sistem pengairan tadah hujan dikarenakan sulitnya mendapatkan air tawar untuk irigasi sawah. Hal itu membuat petani sawah lebih memilih untuk mengkonversi sawahnya menjadi tambak pada tahun 1995 dengan potensi tanah yang memang lebih cocok untuk dijadikan tambak.

Hasil tambak dari pemanenan dikumpulkan di tengkulak yang kemudian dikirim ke pasar ikan yang ada di Jakarta (seperti Muara Baru, Muara Karang dan Ciangke) dan Bandung. Kerjasama petani tambak dengan tengkulak diawali dari peminjaman modal dari tengkulak yang berupa pakan ikan bandeng amaupun udang dan obatobatan untuk ikan dan udang. Kemudian petani membayar pinjaman tersebut dengan hasil tambak yang memang 
dikumpulkan pada tengkulak yang memberi pinjaman tadi, dengan bagi hasil keuntungan antara petani tambak dengan tengkulak dari hasil penjualan. Persentase bagi hasil antara petani tambak dan tengkulak sendiri tergantung pada kesepakatan kedua belah pihak yang sudah disepakati sejak awal peminjaman.

Kondisi dan luas hutan mangrove (hutan bakau) di kawasan pantai utara di wilayah Kab. Indramayu semakin kritis. Dalam 20 tahun terakhir, luas hutan menyusut dari luas semula 8.000 ha menjadi 1.600 ha. Menyusutnya luas lahan mangrove tersebut lebih banyak disebabkan alih fungsi lahan oleh masyarakat pesisir pantai yang menebang hutan mangrove untuk dijadikan tambak, termasuk yang terjadi pada kasus alih fungsi lahan pada Desa Karangsong.

\section{Proses Konversi dan Peran Berbagai Aktor}

Pada tahun 1968, proses awal bagi orang yang ingin memiliki lahan tambak adalah mematok lebih dulu seberapa luas dan bagian mana lahan yang sanggup mereka garap untuk dijadikan tambak. Kawasan yang boleh dibuat tambak pada saat itu masih dibatasi oleh Pemerintah Desa, yaitu tanah timbul yang ada antara batas adanya air payau atau tanggul asin (perbatasan antara bertemunya air asin dan air tawar) hingga ke pantai. Karena proses pembuatan tambak dilakukan sendiri tanpa bantuan kuli maka luas tambak yang dipatok pun tidak terlalu luas. Setelah menentukan wilayah mana yang ingin mereka jadikan tambak, kemudian calon petani tambak mendaftarkan diri pada penitia pembagian lahan tambak mengenai seberapa luas dan lokasi lahan yang ingin mereka jadikan tambak. Panitia pembagian lahan tambak adalah orang-orang utusan atau kepercayaan dari Pemerintah Desa yang bertugas membagikan lahan tambak kepada penduduk yang berminat untuk membuat tambak dan mencatat data-data mengenai hal tersebut yang nantinya disimpan sebagai arsip di Kantor Desa. Kemudian memohon persetujuan berupa Surat Kuasa (SK) yang dilegalisir oleh Kepala Desa (Kuwu). SK yang sudah dimiliki tadi merupakan persyaratan untuk mendapatkan Surat Ijin Menggarap (SIM), selain itu, SK juga harus diperpanjang setiap tahunnya sebagai pembayaran pajak kepada Dinas Pertanahan. Berikutnya petambak harus mengajukan permohonan penukaran SK dengan Kitir yang berupa surat keterangan dari Kepala Desa bahwa lahan tersebut sudah bebas dan sudah menjadi hak milik. Namun pada tahun 1990, Kitir yang dimiliki petambak sudah tidak berlaku lagi dan petambak diwajibkan untuk memiliki sertifikat sebagai bukti nyata penguasaan lahan.

Semakin berkembang dan semakin luas tambak, prosedur yang harus dilakukan untuk memiliki lahan tambak pun sedikit mengalami perubahan dikarenakan keadaan tambak yang sudah lebih baik dari sebelumnya. Keadaan lahan tambak yang sudah jadi (sudah menjadi tambak) dapat meningkatkan harga tambak karena tidak perlu melewati proses pengerukan tanah dan lain sebagainya agar menjadi tambak yang sesuai untuk budidaya ikan dan udang, sehingga hanya orang yang memiliki modal besar yang mampu memiliki tambak. Keberhasilan usaha tambak setiap tahunnya membuat para petani tambak semakin memiliki keinginan untuk mengembangkan dan menambah luas tambak yang dimiliki. Diantaranya adalah melalui kegiatan transfer tambak atau jual beli tambak antara penduduk desa maupun luar desa (desa tetangga).

Kegiatan jual beli atau sewa tambak sebenarnya sudah ada sejak dibukanya tambak oleh penduduk lokal, namun keadaan tiga desa saat itu (Desa Brondong, Pabean Udik dan Karangsong) masih merupakan satu desa, sehingga kegiatan transfer tambak antar desa dapat dikatakan dimulai sejak pemekaran Desa Brondong menjadi tiga desa hingga sekarang.

Prosedur yang harus dijalani terkait peraturan dan perijinan jual beli maupun sewa-menyewa dengan keadaan tambak yang sudah jadi (sudah menjadi tambak) melibatkan beberapa aktor, diantaranya adalah pembeli/penyewa tambak, penjual/yang menyewakan tambak, dan Aparat Desa mencakup Kepala Desa. Setelah terjadi persetujuan mengenai biaya dan peraturan jual beli atau sewa-menyewa antara penjual dan pembeli atau penyewa dan yang menyewakan, kemudian aktor-aktor tersebut tadi mengajukan permohonan surat perubahan hak penguasaan bagi pembeli dan surat keterangan sewa bagi penyewa yang ditandatangani oleh Kepala Desa sebagai bukti yang sah. Namun dari berbagai rangkaian konversi tadi tidak sedikitpun terlihat adanya keterlibatan dengan Dinas Kehutanan dan Perkebunan (Dishutbun). Namun pada saat Kabupaten Indramayu mengalami kerusakan pesisir dan kerusakan mangrove, Dishutbun mulai memberikan perhatiannya pada Desa Karangsong dalam bentuk pelatihan dan kerja sama mengenai pengelolaan mangrove.

\section{Karakteristik Pelaku Tambak Desa Karangsong}

\section{Umur dan Pendidikan}

Karakteristik pelaku tambak berdasarkan umur terbagi menjadi tiga seperti yang dijelaskan oleh Kamaluddin (1994), yaitu: (1) Usia tidak produktif, yaitu umur $<25$ tahun dan >65 tahun; (2) Usia produktif, yaitu umur $>45$ tahun sampai dengan umur 65 tahun, dan (3) Usia sangat produktif, yaitu umur 25 tahun sampai dengan 45 tahun.

Umur pelaku tambak sebagian besar berada pada rentang 25 - 25 tahun atau dalam kategori usia sangat produktif yaitu dengan persentase 56,52\% atau sebanyak 13 dari 23 responden. Sedangkan pada rentang usia tidak produktif dan usia produktif masing-masing adalah sebanyak 5 responden atau dengan persentase $21,74 \%$.

Sebagian besar pelaku tambak yang menjadi responden dalam penelitian ini memiliki karakteristik pendidikan pada jenjang atau setara Sekolah Dasar (SD) yaitu sebanyak 11 dari 23 responden atau 50\%. Pada jenjang pendidikan setara Sekolah Menengah Pertama (SMP) adalah sebanyak 7 responden atau $31,82 \%$ dan 1 responden pada jenjang pendidikan lulusan Sekolah Menengah Atas (SMA) atau setara dengan 4,55\%. Sedangkan responden dengan karakteristik pendidikan pada jenjang Perguruan Tinggi (PT) adalah sebanyak 3 responden atau $13,63 \%$.

Karakteristik berdasarkan umur pada responden pelaku tambak menunjukkan sebagian besar adalah berada pada usia sangat produktif. Jika dikorelasikan dengan karakteristik pendidikan yang responden miliki pada 
Tabel 6, sebagian besar responden memiliki karakteristik pendidikan pada jenjang pendidikan Sekolah Dasar (SD). Bagi responden petambak, tidak banyak pekerjaan yang bisa dilakukan oleh mereka dengan lulusan bahkan tidak tamat SD selain pekerjaan serabutan seperti menjadi buruh dan sebagainya. Oleh karena itu menurut penjelasan beberapa responden, sejak mereka tidak melanjutkan pendidikan lagi, mereka mulai membantu orang tua yang kebetulan adalah petani tambak hingga akhirnya mengurusi tambak yang mereka miliki sendiri pada usia yang sangat produktif berbekal pengetahuan dari mengurusi tambak milik orang tua mereka.

\section{Jenis Pekerjaan Utama}

Sebagian besar pekerjaan utama pelaku tambak adalah sebagai petani tambak yaitu sebanyak 18 dari 23 responden atau dengan persentase 78,25\%. Profesi sebagai petambak tidak dapat sembarang dikombinasikan dengan pekerjaan lain. Misalnya seseorang yang berprofesi sebagai petambak tidak bisa berprofesi juga sebagai nelayan besar. Hal tersebut dikarenakan profesi sebagai petambak membutuhkan banyak waktu untuk mengelola tambak. Begitu juga profesi sebagai nelayan besar yang menghabiskan sebagian besar waktunya berada di laut. Namun sebaliknya, tidak sedikit mantan nelayan yang memiliki tambak karena sebagian besar waktu mereka adalah berada di darat, namun dengan umur mendekati usia tidak produktif.

\section{Luas lahan Tambak}

Luas tambak yang dimiliki pelaku tambak sebagian besar adalah berada pada luas $\leq 5$ ha yaitu sebanyak 16 dari 23 responden atau dengan persentase $74 \%$. Sebaliknya pelaku tambak yang memiliki luas tambak $>5$ ha adalah sebanyak 6 orang responden atau $26 \%$.

Sebagian besar luas tambak yang dimiliki petani tambak rata-rata adalah 2 ha. Pelaku tambak yang memiliki luas tambak > 5 ha merupakan hasil ekspansi mereka selama bertahun-tahun. Sebagaian besar dari mereka yang memiliki luas tambak $>5$ ha merupakan responden dengan umur mendekati usia tidak produktif. Mereka mengekspansi luas lahan yang mereka miliki dengan bermacam cara, diantaranya adalah warisan dari orang tua, hasil dari pelaku tambak lain yang menggadaikan lahan tambaknya namun tidak sanggup untuk membayarnya kembali kemudian menjualnya kepada yang memberikan pinjaman, maupun sengaja membeli lahan tambak dari pelaku tambak yang lain.

\section{Status Penguasaan Lahan}

Responden pelaku tambak memiliki status penguasaan terhadap tambaknya sebagian besar adalah sebagai pemilik yaitu sebanyak 14 dari 23 orang atau $60,87 \%$. Pelaku tambak sebagai penyewa hanya 5 responden atau $21,74 \%$ saja. Sedangkan pelaku tambak yang memiliki status penguasaan sebagai penggarap hanya berjumlah 4 responden atau persentase sebnyak $17,39 \%$.

Status penguasaan sebagai penyewa pada pelaku tambak dikerenakan ketidakmampuan pelaku tambak untuk membeli lahan tambak dengan harga yang tinggi. Dibandingkan dengan harga tambak pada masa sekarang, harga tambak pada awal pembukaan lahan masih sangat rendah karena uang yang dikeluarkan hanya sebagai upah jasa panitia pembagian lahan seperti yang dijelaskan pada penjelasan sebelumnya. Sebaliknya pelaku tambak sebagai penggarap, diantaranya adalah karena tambak yang digarap masih milik orang tua atau saudara mereka dengan pembagian hasil sesuai kesepakatan yang dibuat oleh kedua pihak. Namun diantara mereka juga ada yang bekerja sebagai penggarap yang menggarap lahan tambak orang lain untuk mendapatkan keuntungan tambahan sebagai pekerjaan sampingan.

\section{DAMPAK KONVERSI MANGROVE DAN UPAYA REHABILITASINYA}

\section{Dampak Konversi Mangrove}

Kegiatan konversi mangrove skala besar di Desa Karangsong dikarenakan jumlah permintaan terhadap tambak begitu tinggi dengan keadaan mangrove yang dirasakan penduduk saat itu tidak memberikan keuntungan lebih dibandingkan dengan keuntungan yang didapat dari usaha budidaya pada tambak. Namun kerusakan mangrove akibat konversi skala besar tersebut juga tentunya memberikan dampak terhadap penduduk lokal disekitarnya baik keuntungan maupun kerugian dalam jangka waktu yang langsung maupun tidak langsung. Berdasarkan wawancara mendalam dengan beberapa responden dan informan mengenai dampak konversi mangrove tersebut, terdapat beberapa dampak yang dirasakan, diantaranya:

\section{a. Keuntungan}

Responden dan informan tidak banyak memberikan penjelasan mengenai keuntungan dari konversi mangrove. Namun setelah adanya konversi mangrove menjadi tambak sejak tahun 1968 sebagai munculnya kegiatan ekonomi baru, keadaan perekonomian penduduk lokal Desa Karangsong secara keseluruhan lebih baik dari sebelumnya. Berdasarkan hasil dari wawancara mendalam dengan beberapa responden dan informan, dapat disimpulkan bahwa konversi mangrove dapat membantu menaikkan pendapatan dan kesejahteraan masyarakat di Desa Karangsong sesuai dengan tujuan Pemerintah Desa. Oleh karena itu, Pemerintah Desa telah memfasilitasi tanah timbul dan konversi mangrove skala kecil menjadi tambak untuk semua lapisan penduduk Desa Karangsong yang ingin memiliki tambak.

\section{b. Kerugian}

Berbagai kerugian akibat habisnya mangrove dapat dirasakan penduduk lokal yang berpengaruh pada kondisi ekonomi maupun ekologi. Konversi mangrove dalam skala besar tanpa menyisakan tanaman mangrove disekitarnya memberikan pengaruh terhadap biaya produksi yang cenderung lebih tinggi dalam membudidayakan ikan bandeng dibandingkan dengan konversi mangrove dalam skala kecil yang masih. Dalam memberi pakan bandeng, petani tambak perlu memberikan pakan buatan atau pakan pelet sebagai makanan utama bandeng, dibandingkan dengan sebelum adanya konversi berlebihan dan masih menyisakan tanaman mangrove di sekitar pesisir, maupun di area pertambakan. Selain tanaman mangrove sebagai tempat berteduh ikan, para petani tambak pun sadar bahwa 
berbagai mikro organisme pada akar-akar mangrove atau burung sebagai fauna habitat mangrove yang menjatuhkan kotorannya ke tambak akan menjadi lumut dan dapat memberikan pakan alami bagi ikan bandeng. Oleh karena itu, dengan tidak adanya mangrove, maka fauna habitat mangrove pun juga tidak ada sehingga pakan alami untuk ikan bandeng pun tidak tersedia dan mempengaruhi pertumbuhan bandeng yang mampu memakan waktu lebih lama. Jangka waktu pemanenan bandeng dapat mencapai tujuh hingga sebelas bulan dibandingkan dengan pakan alami yang hanya membutuhkan waktu empat bulan saja.

Konversi mangrove dalam skala besar juga telah banyak mempengaruhi kondisi tanah yang cocok untuk budidaya udang windu, sehingga banyak petani tambak yang tidak bisa membudidayakan udang windu di tambak mereka. Selain itu, kerugian pun dijelaskan oleh beberapa responden yang memiliki tambak dekat dengan bibir pantai, yaitu keadaan tambak yang gersang tanpa mangrove membuat tanggul-tanggul tambak menjadi mudah longsor dan terkena abrasi. Kerugian juga tidak hanya dirasakan oleh penduduk yang memiliki tambak, namun penduduk non petambak pun seperti pencari kerang dan nelayan kecil merasakan dampak yang diakibatkan konversi lahan dalam skala besar.

Keberadaan biota air payau seperti kerang, kepiting dan lainnya tidak akan mampu bertahan dan berkembang biak dalam keadaan mangrove yang rusak. Hal tersebut dikarenakan keadaan mangrove yang rusak akan mempengaruhi habitat dan ekosistem disekitarnya sehingga berpengaruh pula pada para pencari kerang dan kepiting yang kehilangan pendapatan akibat sulitnya menemukan kerang maupun kepiting. Kerugian yang dirasakan menurut responden yang bermatapencaharian sebagai nelayan kecil yang mencari ikan dengan perahu adalah hasil tangkap dan jarak melaut. Sulitnya mendapatkan ikan dalam jarak melaut yang dekat atau sekitar laut bagian dangkal membuat mereka harus menempuh jarak melaut yang sedikit lebih jauh ke arah tengah laut untuk mendapatkan hasil tangkap yang lebih banyak. Hal tersebut dikarenakan tidak adanya mangrove sebagai penyambung ekologi darat dan laut dan juga sebagai tempat asuhan atau pemijahan bagi hewan-hewan muda yang akan tumbuh menjadi hewan dewasa.

Selain kerugian ekonomi yang banyak dirasakan penduduk, kondisi ekologi pada pesisir juga mendapatkan dampaknya. Seperti terjadinya abrasi yang terus menggerus pantai Desa Karangsong yang dapat dibuktikan dengan kondisi pantai Karangsong yang semakin habis dari tahun ke tahun.

Namun berbagai kerugian yang dirasakan tersebut, masih belum memberikan kesadaran pada penduduk mengenai pentingknya ekosistem mangrove. Hal tersebut terbukti dengan masih sedikitnya partisipasi penduduk dalam proses rehabilitasi hutan mangrove yang ada di Desa Karangsong tersebut.

\section{Proses dan Aktor Rehabilitasi Mangrove}

Desa Karangsong memiliki areal lahan penghijauan di kawasan bibir pantai yang juga termasuk kawasan green belt dengan tanaman dominan adalah mangrove.
Penanaman mangrove itu mulai aktif dilaksanakan sejak adanya tawaran kerja sama penghijauan kawasan pesisir dari Wetlands International dengan Desa Karangsong yang ditangani oleh kelompok bernama Kelompok Pelestari Lingkungan (Kelopak) pada tahun 1998 melalui persemaian di lahan tambak sewaan milik petani tambak. Selain mangrove yang sengaja disemai di lahan tambak sewaan, mangrove jg ditanami di sekitar saluran irigasi tambak.

Program kerja Kelopak itu sendiri sebenarnya hanya memfokuskan pada tambak yang berbasis lingkungan, sehingga program kerja yang dibuat pun sebagian besar terfokus pada tambak. Program Kelopak yang diperkenalkan kepada petani tambak yang berkaitan dengan mangrove adalah menyisakan beberapa persen yang dimiliki petambak untuk ditanami mangrove. Kelopak hanya mampu bertahan sejak tahun 1998 hingga tahun 2003 saja karena berbagai hal internal dari kelompok itu sendiri yang membuat adanya perbedaan sehingga pengelolaan kelompok menjadi tidak jelas dan tidak bertahan lagi.

Sejak tahun 2003, mangrove yang telah tumbuh tidak terpelihara karena tidak adanya pengelolaan. Pada tahun 2007 berdiri kelompok baru yang diberi nama Kelompok Pantai Lestari. Kelompok Pantai Lestari berdiri dengan pembentukan panitia baru yang memang memfokuskan pada penghijauan pesisir. Ide awal terbentuknya Kelompok Pantai Lestari dimulai dari pembicaraan santai antara seorang Kepala Desa dengan lima orang penduduk Desa Karangsong yang peduli terhadap keadaan pesisir Karangsong yang semakin rusak dan keadaan mangrove hasil persemaian yang terbengkalai. Dimulai dari keenam orang tadi, yang terdiri dari Alm. Pak Lani (Kepala Desa Karangsong), Pak Tarika (orang terdekat/sahabat Alm. Pak Lani), Pak Makrus (Guru SD), Pak Carita (ketua RT), dan dua lainnya adalah petani tambak. Kelompok Pantai Lestari mulai berdiri dengan kepengurusan berdasarkan keputusan bersama diantara kelima pendiri tadi sebagai pengurus inti.

Ketua kelompok yang dipilih berdasarkan kedekatan individu dengan Kepala Desa demi mendapatkan kemudahan dalam pengakuan kelompok yang didirikan yang pada saat itu menjabat sebagai Kepala Desa adalah Pak Lani (Alm) dengan ketua kelompok Pak Tarika. Setelah terbentuk kepengurusan, kelompok mencoba membuat beberapa program berdasarkan ide dari masingmasing pengurus tadi dan mulai merekrut anggota dari masyarakat Desa Karangsong lainnya.

Perekrutan anggota diawali dengan mengajak orang sekitar yang memiliki kemauan dan kepedulian terhadap lingkungan, selain itu anggota yang bisa memberikan kontribusi lebih berupa alat-alat (seperti perahu kecil) yang dapat membantu jalannya program pun lebih diutamakan karena dana awal kelompok didapatkan dari dana swadaya pengurus dan anggota sendiri tanpa bantuan dari luar.

Kegiatan yang pertama dilakukan oleh Kelompok pantai Lestari adalah mengikuti pelatihan. Pelatihan itu sendiri dapat terlaksana dari kerja keras kelompok yang melakukan pendekatan dengan Dinas Kehutanan dan 
Perkebunan Kabupaten Indramayu. Melalui pendekatan tersebut, Kelompok Pantai Lestari mulai aktif mendapatkan undangan pelatihan. Selain itu, pendekatan dengan Dinas Kehutanan dan Perkebunan, LSM dan berbagai perusahaan juga dapat mempermudah proses pengajuan proposal.

\section{Karakteristik Penduduk Aktor Rehabilitasi Mangrove}

\section{Umur}

Karakteristik berdasarkan umur merupakan salah satu pengaruh terhadap seberapa besar partisipasi penduduk dalam kegiatan rehabilitasi mangrove. Terbukti dengan adanya karakteristik sembilan responden aktor rehabilitasi pada Tabel 10 yang menunjukkan bahwa hampir seluruh responden atau delapan dari sembilan orang responden berada pada usia produktif dan sangat produktif. Kriteria usia produktif maupun sangat produktif cenderung lebih aktif berpartisipasi dibandingkan dengan usia yang sudah tidak produktif lagi.

Sebagian besar karekteristik responden aktor rehabilitasi berada pada golongan usia sangat produktif, yaitu sebanyak 6 dari 9 responden $(66,67 \%)$. Sedangkan responden aktor rehabilitasi usia produktif hanya 2 orang $(22,22 \%)$ dan 1 orang $(11,11 \%)$ berada pada usia tidak produktif. Aktor rehabilitasi yang masih aktif pada usia yang sudah tidak produktif lagi dikarenakan adanya ketertarikan responden untuk mendapatkan keuntungan materi dengan menjadi anggota kelompok rehabilitasi mangrove sebagai kuli tanam yang diupah setiap adanya kegiatan penanaman per harinya.

\section{Pendidikan}

Tingkat pendidikan juga mempengaruhi bagaimana individu berpartisipasi dalam suatu kegiatan, seperti pada kegiatan rehabilitasi mangrove pada penelitian ini. Disamping itu, tingkat pendidikan juga mempengaruhi motivasi dalam berpartisipasi.

Berdasarkan wawancara dengan responden aktor rehabilitasi, dapat disimpulkan bahwa responden dengan tingkat pendidikan lebih tinggi memiliki motivasi partisipasi lebih variatif. Selain motivasi karena kesadaran mereka terhadap pentingnya ekosistem mangrove, mereka juga bisa mencari keuntungan dengan mengikuti kegiatan tersebut seperti dengan mengikuti pelatihan, mereka bisa menerapkan tambak ramah lingkungan berbasis penghijauan pesisir berdasarkan pengetahuan yang mereka miliki dari pelatihan dan memiliki nilai ekonomi bagi mereka. Sementara responden dengan pendidikan rendah, motivasi mereka untuk berpartisipasi dalam kegiatan rehabilitasi hanya untuk mendapatkan keuntungan berupa upah dari kegiatan penanaman mangrove seperti yang telah dijelaskan sebelumnya.

Pada Tabel 11, terdapat 1 orang $(11,11 \%)$ dari 9 responden aktor rehabilitasi yang tidak mengenyam pendidikan, sedangkan 2 orang responden $(22,22 \%)$ pada tingkat pendidikan SD, 5 orang responden $(55,56 \%)$ pada tingkat pendidikan SMA dan 1 orang responden $(11,11 \%)$ pada tingkat perguruan tinggi.

\section{Jenis Pekerjaan Utama}

Terdapat 3 orang $(33,34 \%)$ dari 9 responden yang memiliki pekerjaan utama sebagai petambak. Pekerjaan 3 orang aktor sebagai petambak tersebut dijadikan suatu peluang kemudahan bagi mereka untuk memberikan contoh petambak yang pro dengan kegiatan rehabilitasi. Dengan kegiatan mereka sebagai petani tambak, mereka bisa menjadikan tambak mereka sebagai percontohan bagi petani tambak yang lain untuk memulai program tambak ramah lingkungan dengan sistem tambak tumpang sari atau tambak silvofishery maupun program rehabilitasi lainnya. Selain karena menyadari pentingnya mangrove bagi tambak, motif lain dari petambak pro rehabilitasi tersebut juga untuk mendapatkan keuntungan materi dari keberhasilan program kegiatan percontohan silvofishery yang belum dilakukan oleh petambak lain di Desa Karangsong.

Selain sebagai petani tambak, pekerjaan utama responden aktor rehabilitasi lainnya adalah sebagai pedagang adalah sebanyak 2 orang ( $22,22 \%), 2$ orang $(22,22 \%)$ sebagai nelayan. Dari 9 responden juga terdapat aktor rehabilitasi yang memiliki pekerjaan utama sebagai Pegawai Negeri Sipil (PNS) atau sebagai guru yaitu sebanyak 1 orang $(11,11 \%)$ dan 1 responden lagi $(11,11 \%)$ bekerja di sebagai perangkat desa.

\section{Program Kelompok Rehabilitasi dan Kendala yang Dihadapi}

Kepengurusan inti Kelompok Pantai Lestari terdiri dari 5 orang, diantaranya menjabat sebagai Ketua, Sekertaris, Bendahara dan Ketua Bidang dengan tugas yang berbeda pada masing-masing bagian. Ketua kelompok sendiri dipilih berdasarkan kedekatan individu dengan Kepala Desa (Kuwu) yang menjabat pada masanya dengan tujuan mempermudah perijinan mengenai program yang dimiliki kelompok.

Berdasarkan wawancara dengan informan dari Kelompok Pantai Lestari, program dasar yang dimiliki oleh kelompok terbagi menjadi tiga, yaitu:

a. Penghijauan. Program ini terbagi dalam beberapa program lainnya yang terkait kedalam penghijauan, yaitu seperti pengadaan greenbelt (jalur hijau) atau zona penyangga dengan penanaman, persemaian dan penyulaman mangrove. Kegiatan tersebut juga didukung dengan pola agroforestry seperti penanaman kelapa dan tanaman pertanian lainnya. Selain itu, penanaman cemara dan pembuatan rumah ikan dari terumbu karang juga satu persatu akan dilaksanakan. Diantara beberapa program penghijauan tersebut, program pengadaan zona penyangga dengan penanaman, persemaian dan penyulaman mangrove sudah terlaksana dengan sebagian besar tanaman berumur empat tahun. Penanaman mangrove dengan jenis Avicennia sp., Bruguiera sp. dan Rhizophora sp. ini dapat dikatakan berhasil karena mangrove Desa Karangsong telah dinobatkan sebagai Desa Percontohan dalam rehabilitasi mangrove. Sedangkan program lainnya masih dalam tahap percobaan.

b. Usaha dan Pemberdayaan. Kedua program tersebut memiliki satu tujuan yang sama yaitu pemberdayaan 
dan peningkatan kesejahteraan masyarakat melalui cara pengembangan usaha. Kelompok Pantai Lestari masih dalam tahap mengupayakan untuk dapat membuat wisata alam pesisir dan kuliner dengan dukungan keadaan mangrove dan pesisir yang baik. Dengan adanya wisata alam tersebut mampu memberikan lapangan kerja bagi penduduk Desa Karangsong dengan membuka usaha sebagai pegawai tempat wisata, pedagang, dan lainnya. Selain itu, berbagai bentuk upaya kelompok agar penduduk Desa Karangsong lebih berdaya dalam mencapai kesejahteraan yang berkaitan dengan tambak adalah diadakannya percontohan empang tumpangsari (silvofishery) dengan rumput laut (tambak ramah lingkungan), budidaya kerang dan budidaya kepiting. Percontohan tersebut dilakukan oleh pengurus dan anggota kelompok sendiri pada tambak yang mereka miliki. Selain itu kelompok juga mengadakan sosialisasi secara tidak langsung yang dimulai dari petani tambak yang ditemui di kawasan tambak mengenai program pemberdayaan yang dimiliki kelompok.

Upaya pencapaian keberhasilan program rehabilitasi di atas juga menemui beberapa kendala, diantaranya adalah konflik perebutan lahan antara kelompok rehabilitasi dengan petambak. Konflik yang sampai sekarang masih dirasakan kelompok adalah masalah Surat Kuasa (SK) lahan milik pemerintah yang diperebutkan oleh Kelompok Pantai Lestari dengan tujuh orang penduduk. Lahan yang dimanfaatkan kelompok pada awalnya memang sudah lebih dulu dipatok oleh penduduk sejak adanya pembagian tanah untuk tambak oleh Pemerintah Desa, namun lahan tersebut belum memiliki SK yang yang menjadi surat pernyataan kuasa lahan, maka dengan berbagai cara kelompok pun mencoba melakukan pendekatan kepada Pemerintah Desa agar diijinkan mengambil alih dan membuat SK atas lahan yang memang masih milik pemerintah tersebut untuk dijadikan kawasan greenbelt atau zona penyangga pantai.

Kendala berikutnya adalah keberhasilan beberapa program kelompok Pantai lestari tersebut tidak terlalu banyak melibatkan penduduk lokal Desa Karangsong. Partisipasi penduduk hanya sekedar sebagai buruh tanam yang membantu kelompok untuk menanami mangrove dengan diberikan upah. Hal tersebut dijelaskan oleh informan, penduduk kurang bersedia bekerja dengan sukarela karena fokus mereka masih kepada keuntungan materi yang merupakan keuntungan dalam jangka pendek untuk memenuhi kebutuhan individu mereka dibandingkan dengan manfaat ekologi yang memberikan keuntungan bersama walaupun dalam jangka panjang. Dengan terlibatnya penduduk sebagai buruh tanam pun sudah menjadi anggota Kelompok Pantai Lestari, bahkan mereka juga bisa menjadi buruh tetap untuk menanam mangrove dengan upah Rp.50.000.- per hari.

Keuntungan ekonomi yang didapatkan oleh pengurus inti kelompok Pantai Lestari tidak begitu seberapa dibandingkan dengan tenaga yang telah mereka keluarkan. Namun disisi lain, mereka mendapatkan banyak ilmu mengenai mangrove, memiliki banyak rekan kerja baru baik dari Dinas Kehutanan dan Perkebunan,
LSM dan sebagainya. Kerjasama baik yang terbentuk antara kelompok dengan berbagai instansi tersebut juga memberikan keuntungan tersendiri bagi masing-masing pengurus kelompok karena udangan kegiatan pelatihan mengenai mangrove dari berbagai instansi tadi juga sekaligus bisa dijadikan rekreasi bagi kelompok karena tempat pelaksanaan kegiatan pelatihan tersebut bisa sampai ke luar Jawa seperti Bali.

\section{PERSEPSI PENDUDUK DAN PROSPEK MANGROVE}

\section{Persepsi Responden Terhadap Rehabilitasi Mangrove}

Persepsi yang dimaksud dalam penelitian ini adalah sudut pandang individu dalam menilai suatu hal yaitu mangrove kaitannya dengan penelitian ini. Persepsi berdasarkan responden terbagi kedalam dua bagian, diantaranya adalah persepsi responden petambak dan persepsi responden non petambak. Maka persentase persepsi dari petambak dan non petambak mengenai rehabilitasi mangrove dengan keadaan konversi menjadi tambak yang ada pada saat ini, dapat dilihat pada Tabel 2.

Tabel 2. Persepsi Responden Terhadap Rehabilitasi Mangrove

\begin{tabular}{lrrrr}
\hline \multirow{2}{*}{ Interval Skor Persepsi } & \multicolumn{2}{c}{ Petambak } & \multicolumn{2}{c}{ Non Petambak } \\
\cline { 2 - 5 } & Jumlah (orang) & Persentase (\%) & Jumlah (orang) & Persentase (\%) \\
\hline $13 \leq x \leq 18$ & 7 & 30,43 & 4 & 36,36 \\
$\begin{array}{l}\text { (Tinggi) } \\
7 \leq x \leq 12\end{array}$ & 14 & 60,87 & 7 & 63,64 \\
$\begin{array}{l}\text { (Sedang) } \\
0 \leq x \leq 6\end{array}$ & 2 & 8,70 & 0 & 0 \\
(Rendah) & 23 & 100,00 & 11 & 100,00 \\
\hline Jumlah & & & & \\
\hline
\end{tabular}

Dapat dilihat pada Tabel 2 bahwa 14 responden petambak $(60,87 \%)$ memiliki persepsi kategori "Sedang", yaitu persepsi dengan jumlah skor yang diperoleh dari skor ragu-ragu yang tinggi terhadap adanya kegiatan rehabilitasi mangrove dalam kondisi konversi yang ada sekarang di Desa Karangsong. Tingginya skor ragu-ragu yang diberikan responden petambak terhadap rehabilitasi mangrove dapat dipandang juga sebagai sikap netral atau lemahnya inisiatif dari responden untuk berperan serta dalam kegiatan rehabilitasi. Sebanyak 7 orang responden $(30,43 \%)$ memiliki persepsi kategori "Tinggi", yaitu persepsi responden dengan dasar dukungan dan motivasi positif untuk berperan serta dalam kegiatan rehabilitasi mangrove, dan 2 responden lainnya $(8,70 \%)$ yang memiliki persepsi dengan kategori "Rendah", yaitu tidak adanya motivasi maupun inisiatif untuk berperan serta dalam kegiatan rehabilitasi. Begitu juga pada responden non petambak, dari 11 orang responden, sebanyak 7 orang responden $(63,64 \%)$ memiliki persepsi kategori "Sedang" dan 4 orang $(36,36 \%)$ memiliki persepsi kategori "Tinggi" terhadap kegiatan rehabilitasi yang ada di Desa Karangsong.

Responden petambak maupun non petambak memiliki persentase perepsi kategori "Sedang" yang sama-sama tinggi. Namun responden non petambak memiliki persentase persepsi kategori "Tinggi" sedikit lebih tinggi terhadap rehabilitasi mangrove dibandingkan dengan responden petambak. Hal itu disebabkan karena responden non petambak tidak memiliki kaitan dengan 
tambak, berbeda halnya dengan responden petambak. Terdapat beberapa konflik yang terjadi antara aktor rehabilitasi dengan petani tambak mengenai penanaman mangrove sehingga mempengaruhi persepsi antara responden petambak dengan responden non petambak.

Akar mangrove jenis Rhizophora sp. atau lebih dikenal dengan tanaman bakau bisa menggangu penjaringan ikan maupun udang karena jaring mudah tersangkut dan robek. Selain itu jenis akar bakau yang merupakan akar tunjang (akar yang tumbuh di atas permukaan tanah, mencuat dari batang pohon dan dahan paling bawah serta memanjang ke luar dan menuju ke permukaan tanah) juga bisa menjadi sarang hama ular yang memangsa nener atau ikan bandeng muda maupun udang budidaya. Hampir seluruh dari 23 responden petambak setuju diadakan penanaman mangrove di lokasi tambak, namun cukup di sekitar aliran irigasi tambak saja. Selebihnya menyatakan tidak setuju karena selain merugikan petambak jika menanam mangrove pada tanggul, mangrove yang di tanam di sisisisi saluran irigasi juga bisa menyebabkan pendangkalan akibat sedimentasi jika penanaman tidak mendapatkan pengawasan dan pemeliharaan secara berkelanjutan.

Seluruh responden menyetujui dan memberikan komentar positif terhadap kegiatan rehabilitasi yang dilakukan Kelompok Pantai Lestari dengan lokasi di bibir pantai. Namun peraturan desa yang ada tidak begitu jelas diketahui beberapa responden. Dari 34 responden yang diwawancarai, hampir seluruhnya tidak mengetahui apa saja peraturan desa mengenai pemanfaatan dan pengelolaan mangrove. Mereka hanya mengetahui peraturan yang secara tidak langsung disampaikan oleh kelompok rehabilitasi melalui pembicaraan santai bahwa menebang kayu mangrove adalah tindakan yang dilarang. Namun selebihnya masih belum ada sosialisasi secara formal dari pemerintah desa mengenai pengenalan peraturan tersebut.

\section{Perspektif Responden Terhadap Rehabilitasi Mangrove}

Berdasarkan hasil wawancara dan analisa persepsi responden, persepsi penduduk lokal terhadap mangrove didasari dengan pengetahuan mengenai manfaat mangrove secara umum yang mereka dapatkan dari mulut ke mulut antar penduduk Desa Karangsong. Seperti misalnya mangrove merupakan tanaman jenis bakau yang berfungsi untuk mencegah abrasi, mencegah longsornya tanggul pada tambak dan merupakan tanaman yang mampu memberikan pakan alami pada ikan maupun udang pada tambak. Namun pemikiran terhadap mangrove yang seperti itu masih belum mampu membuat penduduk Desa Karangsong lebih berpartisipasi aktif dalam kegiatan rehabilitasi sehingga mempengaruhi persepsi mereka dan memberikan penilaian atau sudut pandang yang cenderung netral.

Skala tambak yang semakin besar yang dimiliki petambak, maka semakin tidak terdapat lahan yang cukup untuk menanam mangrove diantara petak-petak tambak yang ada. Mereka tidak bisa menanami tanaman mangrove pada tanggul tambak maupun di tengah tambak karena dapat menyulitkan proses pemanenan.
Bagi nelayan pencari ikan, terdapat dua sudut pandang mengenai mangrove, yaitu menurut nelayan besar dan nelayan kecil. Bagi nelayan besar, ada maupun tidak adanya mangrove tidak begitu berpengaruh bagi mereka, karena banyak atau sedikitnya tangkapan yang mereka dapat dipengaruhi oleh semakin banyaknya perahu yang juga mencari ikan. Namun sebaliknya bagi nelayan kecil yang hanya mencari ikan di tepi laut, mereka sangat merasakan manfaat adanya mangrove, karena saat masih terdapat hutan mangrove, hasil tangkap yang mereka dapat lebih banyak, seperti kerang, kepiting bakau, ikan air payau dan sebagainya.

Bagi non petambak maupun non nelayan, tidak adanya interaksi atau hubungan langsung antara kegiatan mereka sehari-hari dengan mangrove membuat mereka tidak merasakan manfaat langsung dari tanaman mangrove. Namun hal tersebut tidak membuat cara pandang mereka menjadi negatif terhadap mangrove, hanya saja jika dibandingkan antara penduduk non petambak/non nelayan yang memiliki pendidikan tinggi, penduduk non petambak/non nelayan berpendidikan rendah lebih bersikap netral terhadap kegiatan rehabilitasi mangrove karena selain tidak berinteraksi langsung dengan mangrove, pengetahuan mengenai manfaat mangrove pun tidak banyak diketahui oleh mereka.

\section{Partisipasi Penduduk}

Berdasarkan persepsi responden yang telah dibahas pada subbab sebelumnya, sebagian besar responden memiliki motivasi maupun inisiatif yang tidak rendah, dan juga tidak tinggi. Hal tersebut menunjukkan bahwa penduduk Desa Karangsong cenderung bersikap pasif atau netral terhadap kegiatan rehabilitasi mangrove yang ada. Partisipasi penduduk hanya sekedar sebagai buruh tanam yang membantu kelompok untuk menanami mangrove dengan diberikan upah Rp.50.000.- per hari. Hal tersebut dijelaskan oleh informan, penduduk kurang bersedia bekerja dengan sukarela karena fokus mereka masih kepada keuntungan materi yang merupakan keuntungan dalam jangka pendek untuk memenuhi kebutuhan mereka sehari-hari dibandingkan dengan manfaat ekologi yang memberikan keuntungan bersama walaupun dalam jangka panjang.

Hanya terdapat sebagian kecil penduduk saja berinisiatif untuk ikut berpartisipasi dalam upaya merehabilitasi ekosistem mangrove secara sukarela. Dari beberapa yang berpartisipasi tersebut merupakan penduduk sebagian besar adalah petambak. Mereka menyadari bahwa tambak tanpa mangrove juga dapat merugikan tambak mereka. Mereka menanami tumbuhan mangrove di sekitar tambak maupun saluran irigasi karena tambak yang mereka miliki merupakan tambak yang berada di dekat saluran irigasi maupun bibir pantai.

\section{PENUTUP}

\section{Kesimpulan}

Proses terjadinya konversi lahan hutan mangrove menjadi tambak dilakukan oleh aktor atau pelaku yang berasal dari luar Desa Karangsong yaitu penduduk Kecamatan Losari, Cirebon yang sengaja singgah di Desa Karangsong untuk memanfaatkan tanah timbul. Penduduk pendatang dari 
Losari lebih jeli melihat peluang harga jual tanah timbul yang pada saat itu masih rendah dikarenakan penduduk Desa Karangsong sendiri tidak memiliki pengetahuan lebih mengenai manfaat tanah timbul. Namun dengan adanya pendatang dari Kecamatan Losari, penduduk Desa Karangsong sendiri memperhatikan dan belajar mengenai proses budidaya ikan dan udang pada tambak. Luas lahan tanah timbul yang awalnya hanya dimanfaatkan oleh penduduk pendatang dengan skala kecil, lama-kelamaan skala tambak pun berkembang menjadi skala besar hingga merambah lahan hutan mangrove.

Permintaan terhadap lahan tambak semakin tinggi dengan besarnya keuntungan yang didapat dari budidaya tambak seperti yang diketahui penduduk lokal dari penduduk pendatang tadi. Oleh karena itu Pemerintah Desa Karangsong memberikan fasilitas lahan kepada Penduduk Desa Karangsong yang ingin memiliki tambak agar pembagian lahan lebih adil dengan tujuan meningkatkan kesejahteraan perekonomian dan pemberdayaan penduduk Desa Karangsong.

Sisi negatif dari tujuan Pemerintah Desa mengenai pemberian fasilitas lahan untuk budidaya ikan atau udang pada tambak tadi adalah tidak adanya peraturan tegas mengenai pengeloolaan mangrove, sehingga semakin berjalannya waktu mangrove pun semakin habis akibat penebangan yang dilakukan untuk dialih-fungsikan menjadi tambak (konversi).

Gundulnya mangrove membuat LSM Wetlands International peduli untuk mengadakan rehabilitasi mangrove didukung dengan penyuluhan rehabilitasi mangrove pada penduduk di Desa Karangsong, sehingga penanaman mangrove pun mulai aktif dilaksanakan sejak adanya tawaran kerja sama penghijauan kawasan pesisir dari Wetlands International dengan Desa Karangsong yang ditangani oleh kelompok bernama Kelompok Pelestari Lingkungan (Kelopak) pada tahun 1998 melalui persemaian di lahan tambak sewaan milik petani tambak. Namun setelah proyek dari Wetlands selesai, Kelopak pun mulai pasif sehingga pada tahun 1993. Kemudian dibentuk aktor rehabilitasi baru dengan orang-orang yang baru pula. Kelompok tersebut bernama Kelompok Pantai Lestari dan masih aktif sampai saat ini. Kelompok pantai Lestari itu sendiri dibantu oleh instansi-instansi terkait dalam penyediaan bibit, dana maupun pelatihan pengelolaan mangrove.

Pendekatan yang dilakukan oleh kelompok rehabilitasi yang baru adalah dengan mensosialisasikan program yang dimiliki kelompok kepada petambak sekitar lokasi penanaman mangrove sebagai target sosialisasi awal kelompok, sosialisasi dilakukan dengan penjelasan mengenai manfaat penanaman mangrove menggunakan bahasa yang dapat dimengerti oleh penduduk. Sosialisasi tersebut mendapat tanggapan cukup baik dari sebagian petani tambak. Hanya saja untuk lokasi penanaman mangrove sebaiknya lebih disosialisasikan lagi bagaimana dan dimana penanaman yang baik dan juga tidak merugikan petambak.

Persepsi penduduk Desa Karangsong menunjukkan bahwa sebagian besar penduduk Desa Karangsong memiliki persepsi kategori "Sedang" terhadap kegiatan rehabilitasi yang dilakukan oleh Kelompok Pantai Lestari. Hal tersebut merupakan sikap pasif atau sikap kurang adanya inisiatif terhadap kegiatan rehabilitasi yang ada. Sebagian besar persepsi responden berada pada kategori "Sedang" yaitu persepsi dengan jumlah skor yang diperoleh dari skor ragu-ragu yang tinggi terhadap adanya kegiatan rehabilitasi mangrove dalam kondisi konversi yang ada sekarang di Desa Karangsong. Hal tersebut dapat mempengaruhi inisiatif mereka untuk berpartisipasi dalam kegiatan rehabilitasi. Oleh karena itu, hanya 5-10\% diluar aktor rehabilitasi saja yang mau berpartisi secara sukarela dalam merehabilitasi ekosistem mangrove, dan selebihnya berpartisipasi dengan tujuan mendapatkan upah. Selain itu Peraturan Desa yang sudah ada mengenai pengelolaan daerah perlindungan mangrove Desa Karangsong tidak disosialisasikan dengan baik sehingga sebagian besar penduduk tidak mengetahui peraturan yang telah dibuat tersebut.

\section{Saran}

Beberapa hal menjadi rekomendasi dalam penelitian ini diantaranya adalah:

1. Konversi lahan dengan tujuan pembangunan maupun kesejahteraan penduduk merupakan salah satu alternatif yang bisa dilakukan penduduk. Namun konversi yang dilakukan juga perlu mempertimbangkan dampak yang terjadi pada ekologi dan ekosistem sekitarnya.

2. Perlu dilakukannya penyuluhan maupun pelatihan dari kelompok yang bekerjasama dengan Pemerintah Desa dengan tujuan memberikan motivasi dan meningkatkan partisipasi kepada penduduk dalam kegiatan rehabilitasi mangrove.

3. Perlu adanya ketegasan Pemerintah Desa dalam mensosialisasikan Peraturan Desa yang membahas fungsi dan manfaat mangrove kepada penduduk lokal.

4. Perlu adanya perhatian lebih seperti upaya menejemen dan evaluasi dari Dinas Kehutanan maupun instansi terkait konversi dan rehabilitasi yang ada di Desa Karangsong.

\section{DAFTAR PUSTAKA}

Anonim. 2011. Di Indramayu, 8.000 ha Kini Tinggal 1.600 ha http://bataviase.co. id/node/607654

Anwar, Chairil dan Gunawan, Hendra. 2007. Peranan Ekologis dan Sosial Ekonomis Hutan Mangrove dalam Mendukung Pembangunan Wilayah Pesisir. Http://Www.Dephut.Go.Id/Files/Chairil_Hendra.P df

Aqsa, Mohammad. 2010. Rehabilitasi dan Konservasi Mangrove dalam Menunjang Kawasan Konservasi Laut Daerah (Kkld) Selat Tiworo. Http://Mimpi22.Wordpress.Com/2010/10/12/Reha bilitasi-Dan-Konservasi -Mangrove-DalamMenunjang-Kawasan-Konservasi-Laut-DaerahKkld-Selat-Tiworo/

Azis, Nurdiana. 2006. Analisis Ekonomi Alternatif Pengelolaan Ekosistem Mangrove Kecamatan 
Barru Kabupaten Barru. Bogor: Institut Pertanian Bogor.

Calhoun dan Acolella. 1990. Psikologi Tentang Penyesuaian dan Hubungan Kemanusiaan. Ed Ke3, Terjemahan. IKIP. Semarang: Semarang Press.

Departemen Kehutanan. 2006. Inventarisasi dan Identifikasi Mangrove Wilayah Balai Pengelolaan Das Pemali Jratun Provinsi Jawa Tengah. http://www.bpdaspemalijratun.net/data/i_mangrove/Microsoft $\% 20 \mathrm{~W}$ ord $\% 20$

\%2004_Hasil\%20dan\%20Pembahasan.pdf

Departemen Kelautan dan Perikanan. 2009.

Dinas Kehutanan dan Perkebunan Indramayu. 2011. Persiapan Kabupaten Indramayu dalam Pengelolaan Hutan Mangrove Masa Depan. http://hutbunindramayu.blogspot.com/

Haikal. 2008. Pengelolaan Ekosistem Mangrove di Kecamatan Nipah Panjang Kabupaten Tanjung Jabung Timur Jambi. Bogor: Institut Pertanian Bogor.

Hainim K. 1996. Dampak Konversi dan Pengelolaan Lahan Mangrove Terhadap Kehidupan nelayan di Kabupaten Bengkalis. Bogor: Institut Pertanian Bogor.

Harahap. M. Khazali. 2001. Kajian Partisipasi Penduduk dalam Pengelolaan Hutan Mangrove. Bogor: Institut Pertanian Bogor.

Hari, Harmin dan Syafrina, Nur. 2009. Beberapa Fungsi Ekosistem Mangrove. Http://Www.Buturnews. Idrap.Or.Id/Detailopini.Php?Id=55

Harihanto. 2001. Persepsi, Sikap dan Perilaku Masyarakat Terhadap Air Sungai. Bogor: Institut Pertanian Bogor.

Irwan, D Zoer'aini. 2003. Ekosistem Komunitas dan Lingkungan. Prinsip-Prinsip Ekologi. Jakarta: Bumi Aksara.

Jakaria. 2000. Analisis Pengelolaan Hutan Mangrove Kearah Wilayah Pantai Berkelanjutan dan Dampaknya Kepada Kesejahteraan Penduduk di Kabupaten Kutai Propinsi Kalimantan Timur. Bogor: Institut Pertanian Bogor.

Kammaludin LM. 1994. Strategi Penyiapan dan Pengembangan Kualitas Sumberdaya Manusia (SDM) pada Pembangunan Agribisnis Perikanan Indonesia. Makalah Seminar Sehari Himpunan Sosial Ekonomi Perikanan. Bogor: Institiut Pertanian Bogor.

Lalo, Arman. 2003. Kajian Ekologi Ekonomi Dalam Pengelolaan Ekosistem Mangrove Secara Lestari di Kawasan Pesisir Banawa Selatan Kabupaten Donggala. Bogor: Institut Pertanian Bogor.

Maskendari. 2006. Kajian Pengelolaan Ekosistem Mangrove Berbasis Partisipasi Penduduk di Kecamatan Sukadana Kabupaten Ketapang
Provinsi Kalimantan Barat. Bogor: Institut Pertanian Bogor.

Rakhmat, J. 2007. Psikologi Komunikasi. Remaja Rosdakarya. Bandung.

Rochana, Erna. Tidak Ada Tahun. Ekosistem Mangrove dan Pengelolaannya di Indonesia. Http://Www.Freewebs.Com/Irwantomangrove/Ma ngrove Kelola.Pdf

Setiawan, Firman. 2010. Dampak Konversi Hutan Mangrove Menjadi Tambak dan Lahan Kelapa Sawit. http://firmans08.wordpress.com/category/ eksplorasi/konservasi/

Singarimbun, Masri dan Sofian Effendi. 1989. Metode penelitian Survai. Jakarta : Pustaka LP3ES

Sofli. Wan. R. 2003. Kajian Partisipasi Penduduk dalam Pengelolaan Hutan Mangrove. Bogor: Institut Pertanian Bogor.

Suhaeb, Amrani S. 2000. Analisis Kebijakan Pengelolaan Ekosistem Hutan Mangrove di Teluk Kendari. Bogor: Institut Pertanian Bogor.

Susiatik. T. 1998. Persepsi dan Pertisipasi Masyarakat terhadap Kegiatan Pembengunan Masyarakat Desa Hutan Terpadu (PMDHT) di Desa Mojorebo, Kecamatan Wirosari, Kabupaten Dati II Grobogan, Jawa Tengah. Bogor: Institut Pertanian Bogor.

Tambunan, Nurhafni. 1994. Dampak Sosial Ekonomi dari Pemanfaatan Hutan Mangrove di Kecamatan Percut Sei Tuan Deli Serdang Sumatra Utara Terhadap Penduduk Nelayan Disekitarnya. Bogor: Institut Pertanian Bogor.

Ujung Kulon Conservation Society. 2010. Manfaat Penanaman Mangrove. Http://Ucsindonesia.Org/Index.Php?Option=Com_ Content\&View=Article\&Id=74:Manfaat-

PenanamanMangrove \&Catid=1:Latest\&Itemid $=117$

Wikipedia. 2010. Hutan Bakau. http://id.wikipedia.org/wiki/Ekosistem_mangrove

Yuniarti, Ms. 2004. Analisis Kebijakan Ekosistem Mangrove di Kabupatem Bengkalis Propinsi Riau. Bogor: Institut Pertanian Bogor

\section{Lampiran}

Lampiran 1. Peta Lokasi Penelitian Desa Karangsong, Kecamatan Indramayu, Kabupaten Indramayu, Jawa Barat.

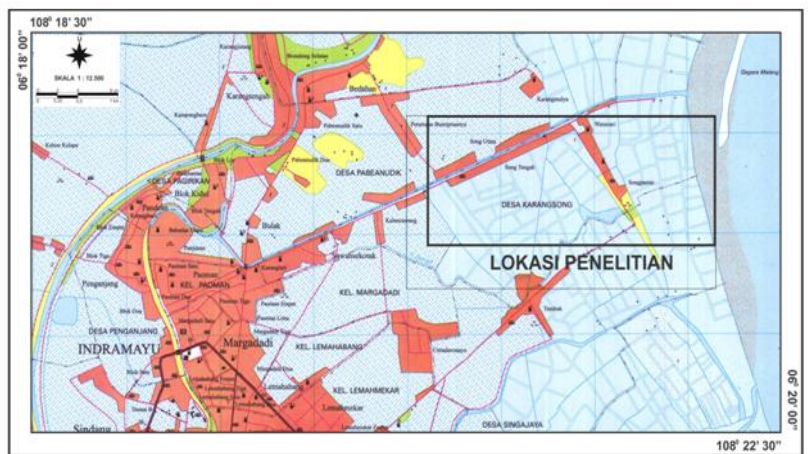

